\title{
DIABETES MELLITUS \\ IN COMBINATION WITH COVID-19: MODERN VIEWS ON THERAPY
}

\author{
LITERATURE REVIEW
}

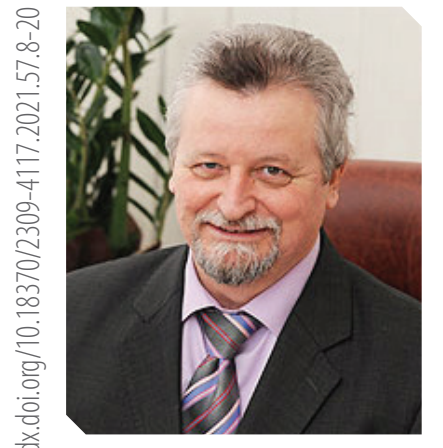

V.I. TSYMBALIUK

$M D$, professor, president of the NAMS of Ukraine, academician of the NAMS of Ukraine, corresponding member of the NAS of Ukraine, Kyiv ORCID: 0000-0001-7544-6603

M.D. TRONKO

MD, professor, vice-president

of the NAMS of Ukraine,

academician of the NAMS

of Ukraine, corresponding member

of the NAS of Ukraine, director

of the SI "V.P. Komisarenko Institute

of Endocrinology and Metabolism

of the NAMS of Ukraine", Kyiv

ORCID: 0000-0001-7421-0981

Y.G. ANTYPKIN

$M D$, professor, academician of the

NAMS of Ukraine, academician-

secretary of the Clinical Medicine

Department of the NAMS of Ukraine,

director of the SI "0.M. Lukyanova

Institute of Pediatrics, Obstetrics

and Gynecology of the NAMS

of Ukraine", Kyiv

ORCID: 0000-0002-8018-4393

S.V. KUSHNIRENKO

MD, associate professor, Department of nephrology and renal replacement

therapy, dean of Therapeutic Faculty,

Shupyk National Healthcare

University of Ukraine, Kyiv

ORCID: 0000-0001-5518-7210

V.V. POPOVA

MD, head of the Department

of Preventive Diabetology,

SI "V.P. Komisarenko Institute

of Endocrinology and Metabolism

of the NAMS of Ukraine", Kyiv

ORCID: 0000-0002-4116-0671

\section{Contacts:}

Viktoriya V. Popova

SI "V.P. Komisarenko Institute

of Endocrinology and Metabolism

of the NAMS of Ukraine",

Department of Preventive Diabetology

Vyshhorodska str. 69

04114, Kyiv, Ukraine

Tel.: +38 (067) 4661534

email:popovavv27@gmail.com

\section{INTRODUCTION}

Coronavirus disease 2019 (COVID-19) is a viral infectious disease caused by the severe acute respiratory syndrome coronavirus 2 (SARS-CoV-2) $[1,2]$. It is an enveloped, single-stranded RNA virus, named for its corona-like protrusions on the surface, visible by electron microscopy [3]. COVID-19 has clinical features similar to Severe Acute Respiratory Syndrome (SARS) and Middle East Respiratory Syndrome (MERS), and viruses belong to the Coronaviridae family and the Coronavirinae subfamily $[2,3]$. They are more similar in their structural and biochemical components.

Cases of pneumonia of unknown etiology occurred in Wuhan, Hubei Province of China in December 2019. The presence of a new coronavirus as a causative agent, which was named Severe Acute Respiratory Syndrome-CoronaVirus-2 (SARS-CoV-2), and the disease that it causes COVID-19, was revealed by advanced analytical sequencing of samples from the lower respiratory tract $[4,5]$.

The articles were searched in the PubMed and Google Scholar databases until February 12, 2021 to write this literature review. The following keywords were used: SARS-CoV-2, COVID-19, coronavirus infection, pathogenesis, pancreas, clinical features, diagnosis, treatment, diabetes mellitus (DM). We also received the full text of the relevant cross-references from the search results. In addition, we have access to currently available scientific literature and guidelines on the websites of the WHO Centers for Disease Control and Prevention (CDC).

Coronavirus infection COVID-19 is a potentially severe acute respiratory infection caused by the SARS-CoV-2 coronavirus, is a dangerous disease that can occur in the form of an acute respiratory viral infection of the mild course, and in a severe form, the specific complications of which may include viral pneumonia, leading to Acute Respiratory Distress Syndrome (ARDS) or respiratory failure at risk of death.

To date, there are no specific antiviral drugs for the treatment or prevention of COVID-19. People with certain comorbid conditions, such as asthma, DM, and heart disease, are more likely to develop severe forms of disease. Means to maintain the functions of vital organs are used in severe cases. The disease is caused by a new virus, people do not have acquired immunity to it, therefore people of all ages are susceptible to infection.

\section{COMORBIDITY AND COVID-19}

As for today, the issues of the relationship and interdependence of COVID-19, and comorbid diseases are the most controversial among all the pathogenetic aspects of the new coronavirus infection.

COVID-19 pathogenesis is currently unknown, but may be similar to the pathogenesis of the SARS-CoV virus. Although the pathophysiological mechanisms have not yet been studied, it has been noted that the most severe and fatal cases of COVID-19 have occurred in the elderly or in patients with concomitant diseases, in particular with the presence of cardiovascular diseases (CVD), DM, chronic lung diseases, kidney diseases, hypertension and oncological diseases $[6,7,8,9]$. According to the WHO, the mortality rate among patients with arterial hypertension reaches $8 \%$, among patients with DM - 9\%. Coronavirus, which causes the disease COVID-19, enters target cells through receptors of a special protein - angiotensin-converting enzyme (ACE2). The virus uses it as an entrance gate. Binding of S-glycoprotein from the coronavirus to ACE2 receptor in the host organism, followed by the cell membrane fusion, initiates virus penetration [10]. S-glycoprotein consists of S1 and S2 subunits located on the spike surface of the virus [11]. It has been documented that levels of furin, a protease that increases viral penetration, is elevated in diabetic patients. An increase in virus penetration occurs due to the cleavage of the $\mathrm{S} 1$ and $\mathrm{S} 2$ domains of the surface spike proteins [12]. Favorable factors for viral replication in the cytosol include an acidic environment and the presence of proteases such as cathepsin [13]. Inflammatory changes are initiated in the respiratory system with the generation of a variety of cytokines and chemokines such as tumor necrosis factor-a (TNF-a); interleukin (IL)-1, IL 7-10; interferon- $\gamma ;$ granulocyte colony-stimulating factor; granulocyte-monocyte colony-stimulating factor; fibroblast growth factor 2; monocytic chemoattractant protein-1; and inflammatory protein of macrophages 1a [4]. At the same time, ACE2 is the target of different drugs (ACE 
inhibitors and angiotensin (Ang) II receptor blockers - sartans), which are widely used in patients with CVD, arterial hypertension, and DM.

\section{PATHOPHYSIOLOGICAL MECHANISMS}

\section{OF COVID-19 AND DIABETES MELLITUS}

DM is a chronic metabolic disorder that currently affects about 422 million people worldwide $[2,14]$. COVID-19 and DM are associated with acute and chronic inflammation, respectively, and can interfere with each other in terms of clinical progression and outcome. Thus, further research is needed on the interplay of these diseases and a possible therapeutic approach to treating DM coexisting with COVID-19. DM is caused either by an absolute lack of insulin in type 1 diabetes (T1D) or by insulin resistance in type 2 diabetes (T2D) [15]. Chronic hyperglycemia is a major metabolic disorder in DM and causes glucose toxicity in body tissues with the formation of advanced glycation end products [16]. These mechanisms are responsible for the chronic complications of DM, which is one of the leading causes of morbidity and mortality worldwide. This condition is associated with macro- and microvascular complications that ultimately affect the overall survival of patients [17]. The link between DM and infection has long been clinically recognized [18]. Infections, especially influenza and pneumonia, are common and more serious in older people with T2D [19, 20]. However, the evidence remains controversial as to whether DM itself increases susceptibility and influences the outcome of infections, or whether CVD and renal comorbidities, which are often associated with DM, are the main causes [21]. It was previously reported that DM and uncontrolled hyperglycemia are significant predictors of severity and risk of death in patients infected with various viruses, including pandemic influenza A (H1N1) [22], SARS-CoV [23] and MERS-CoV [24]. Early researches [6, 7, 25] showed that older patients with chronic diseases, including DM, were at higher risk of developing severe COVID-19 and increased mortality. As is known, DM is a chronic inflammatory condition characterized by multiple metabolic and vascular disorders that determine the response to pathogenic microorganisms [21]. It has been shown that even short-term hyperglycemia temporarily suppresses the innate immune system $[26,27]$. In addition, as described above, DM is characterized by a high proinflammatory cytokine response, especially IL-1, IL-6 and TNF- $a$ in the absence of exogenous immunostimulation. In the presence of an external trigger in patients with $\mathrm{DM}$, a situation of hypercytokinemia, cytokine storm occurs, against the background of COVID-19 complicated by ARDS and systemic multiple organ failure [28]. Hyperglycemia and insulin resistance promote an increase in the synthesis of advanced glycation end products (AGEs) and a sharp increase in the secretion of pro-inflammatory cytokines, an increase in the level of oxidative stress, and also stimulate the production of adhesion molecules that mediate tissue inflammation [21, 29]. This inflammatory process may be the main mechanism that leads to a higher propensity for infections with worse consequences in patients with DM [29]. Some immune defects are considered in strong association with hyperglycemia, although the clinical significance of some in vitro disorders has not yet been fully understood. [28]. On the other hand, poorly controlled DM is associated with in- hibition of the proliferative response of lymphocytes to various triggers [28], as well as with dysfunction of monocytes/macrophages and neutrophils [21]. Abnormal delayed-type hypersensitivity reaction [28] and complement activation dysfunction [29] also described in patients with DM. Older age is associated with defects in T- and B-cell function and excessive dysfunctional production of inflammatory markers. Thus, T2D, either autonomously or in combination with older age, hypertension and/or CVD, may contribute to insufficient control of SARS-CoV-2 replication and a longer pro-inflammatory response, which can lead to fatal outcome $[8,30,31]$. Experimental models have shown that ACE2 receptors are the gateway for coronavirus when it enters human cells. In this regard, it has previously been hypothesized that taking angiotensin-converting enzyme inhibitors (ACEI) and angiotensin receptor blockers (ARBs) may increase the risk of viral infection. To get inside the cell, the SARS-CoV-2 virus binds through its protein $S$ to the ACE2 receptors located on the membranes of the alveolar cells of the lungs, kidneys, myocardium, and intestines, so it is these organs that the new coronavirus can infect. The ACE2 receptor is very important for the entry of SARS-CoV-2 into cells. The receptor is sufficiently expressed by epithelial cells of the lungs, intestines, kidneys and blood vessels. X.C. Li et al. [32] showed that diabetic patients also express high concentrations of ACE2, and that levels are significantly increased in those taking ACEI or ARB. It has been hypothesized that the ACE2 polymorphism is associated with some noncommunicable diseases such as DM, hypertension, stroke, and a genetic predisposition to developing SARS-CoV 2 infection [2]. The SARS-CoV-2 infectivity is related to the rate of release of ACE2. D.W. Lambert et al. [33] showed that disintegrin and metalloproteinase 17 (ADAM17) are capable of separating the ectodomains of some membrane-bound cell adhesion molecules and cytokines, such as the ACE2 molecule. The extracellular domain of ACE2 forms a receptor for the Spike protein (S) of SARS-CoV-2, and this is the main site of the pathogenesis of SARS-CoV-2 infection [34]. Thus, inhibition of ADAM17 leads to a decrease in proteolytic release of the ACE2 ectodomain and ultimately increases the penetration rate and infectivity of SARS-CoV-2 [35]. ADAM17 inhibitors include tissue inhibitory metalloproteinase- 3 and insulin $[36,37]$. Another protease, serine 2 transmembrane protease, counteracts the action of ADAM17 and enhances the uptake of soluble SARS-CoV2 entry by cells through cleavage of ACE2 [38]. Viral entry into host cells is a fundamental component of interspecies transmission, which is especially true for coronaviruses (CoV). When a virus acts on host cells, all CoVs bind through the spike protein to cells that express specific receptors. After binding to target cells, the host cell protease cleaves the spike protein, which allows the virus to enter cells and multiply [39]. ACE2 has been identified as one of the main receptors for both SARS-CoV [40] and SARS-CoV-2 [39]. The interface between ACE2 and the viral spike protein has been deciphered, with the result that the efficiency of ACE2 recruitment is a key factor in the virulence of COVID-19 [41]. ACE2 is widely expressed in the respiratory tracts, heart, kidneys, intestines, brain neurons, endothelium of arteries and veins, immune cells, and pancreas $[42,43]$. Since the ACE2 immunostaining test revealed the presence of ACE2 in the pancreatic islets, it was sug- 
gested that SARS-CoV could damage the $\beta$-cells of the islets of Langerhans and induce the manifestation of autoimmune T1D $[44,45]$. More researches are needed to confirm damage to the pancreas in patients with COVID-19, which certainly contributes to a worsening of the course and prognosis of COVID-19 in patients with onset of DM. As mentioned above, the role of ACE2 in the pathogenesis of DM in association with COVID-19 has been widely discussed in the world scientific literature, and has already been partially studied to date. Given that ACE2 is a functional receptor for SARS-CoV-2, and its expression levels can be increased by ACEl and ARBs, some authors have argued that these drugs may have a negative effect on the course and outcome of the disease in patients with COVID-19 [46]. In contrast, other researchers actively argue that ACEI and ARBs can be very effective in the treatment of coronavirus infection [47], since SARS-CoV and its viral spike protein, after binding to the functional receptor for SARS-CoV-2 - ACE2, reduce the expression of ACE2 in subsequent stages of the disease after reaching, probably, an extremely high level of viremia [48]. As is known, ACE cleaves Ang I to Ang II. Ang II binds to the Ang II receptor 1 and then mediates numerous systemic effects such as stimulating vasoconstriction, promoting normovolemia, regulating the immune system, and local effects in the cardiovascular system. In renin-angiotensin-aldosterone system (RAAS) ACE2 plays the opposite role to ACE. ACE2 catalyzes the conversion of Ang I to Ang-(1-9) and Ang II to Ang-(1-7). Conversion efficiency of ACE2 on Ang II substrate is 400 times higher than on Ang I [49]. Ang(1-7) binds to the G-protein-coupled Mas receptor to mediate various effects including vasorelaxation, cardio protection, antioxidant action [50], anti-inflammatory action [51] and inhibition of Ang II-induced signaling [52, 53]. The ACE2 - Ang-(1-7) axis is considered an important therapeutic target in CVD [54]. A large cohort study showed that circulating ACE2 was found in serum in only 40 out of 534 subjects, and its concentration was about 100 times lower than that of circulating ACE [55]. Additional data have shown that circulating ACE2 is elevated in patients with T1D or T2D, hypertension, heart failure, and chronic kidney disease $[56,57]$. The reason for the high ACE2 levels in these patients is that the increased ACE2 is a protective response to counter the adverse effects of Ang II. Since the expression of AT II - AT1 receptor signaling also contributes to the autoimmune response, ACE2 can control immune functions via the Ang-(1-7) - Mas axis [58, 59]. Ang is produced in the liver and from there into the bloodstream. Renin secreted in the kidneys cleaves Ang to Ang I. Ang I is further converted to Ang II by $A C E$, which is mainly produced in the lungs. Ang II binds to both AT1 and AT2 receptors to regulate blood pressure and inflammation. Most of Ang II's action occurs via the AT1 receptor. Meanwhile, cellular ACE2 is cleaved by ADAM17. After the release of the active form of ACE2 into the extracellular environment, ACE2 converts Ang I to Ang-(1-9) and Ang II to Ang-(1-7). ACE also converts Ang-(1-9) to Ang-(1-7). Ang-(1-7) binds to the Mas receptor to mediate the opposite effects of Ang II. Genetic ACE2 deficiency is associated with activation of inflammatory mediators, increased inflammatory response to pro-inflammatory stimuli, and increased Ang Il-induced heart and aortic remodeling $[60,61]$. The anti-inflammatory effects of ACE2 are mediated primarily through the ACE2 - Ang-(1-7) axis as op- posed to the Ang II - AT1 axis [62]. ACE2 also performs a function independent of the RAAS. Intestinal cellular ACE2 may be another viral entry point for SARS-CoV-2. SARS-CoV-2 enters the human body mainly through the respiratory system, but also, apparently, through the intestines and other tissues. It has been demonstrated that coronaviruses enter the lungs, pancreas, and other human tissues by interacting with the ACE2 receptor. ACE2 expression is much stronger in the pancreatic endocrine tissue compared to exocrine tissue [63]. The extent of SARS-CoV tissue damage is a direct function of the expression level of tissue ACE2. Thus, SARS-CoV viruses can damage the pancreatic islets and cause the onset of DM [64]. In all likelihood, SARSCoV-2 enters the lungs and intestines through cleavage by the protease TMPRSS2 ACE2 [65]. If the immune system is unable to defeat the infection, SARS-CoV-2 will massively replicate, occupy cellular ACE2 and destroy the patient's cells. As a consequence, the Ang II - AT1 system cannot be inactive. At the same time, intestinal function is destroyed, and inflammation is exacerbated. As a result, a cytokine storm manifests, and ultimately the respiratory system, cardiovascular system and other organs lose their functions. Clinical data showed that among inpatients with COVID-19, about 30\% have underlying diseases. These patients are at increased risk of death. Hypertension was most common, followed by DM and coronary artery disease $[8,66]$. Since the Ang II - AT1 axis is already hyperactive in these diseases $[7,67]$, SARS-CoV-2 further reduces the production of functional ACE2. Consequently, patients with these underlying diseases are much more likely to develop a severe course of the disease, quickly transforming into a critical condition. As described above, the RAAS signaling pathway includes both ACE, which metabolizes Ang I to Ang II, and ACE2, which converts Ang II to Ang-(1-7) [68]. In normal physiology, ACE2 cleaves Ang II and, to a lesser extent, Ang I into smaller peptides, Ang-(1-7) and Ang-(1-9), respectively [68]. Ang II has both vasoconstrictor and inflammatory properties, which are balanced by the vasodilatory and anti-inflammatory properties of Ang-(1-7) [68]. The ACE2/Ang-(1-7) system plays an important anti-inflammatory and antioxidant role in protecting the lung tissue from ARDS. The ratio of ACE and ACE2 activity, which are both highly expressed in the lungs, has been shown to affect lung oxygenation and lung damage in ARDS $[68,69]$. Loss of ACE2 function in DM increases Ang II levels and decreases Ang-(1-7) levels both locally in tissues and systemically. Increased Ang II/AT1R signaling initiates the development of multiple pathologies in various organs, increasing the amount of reactive oxygen species and promoting fibrosis, hypertrophy, and inflammation, aggravated by the loss of the protective effects of Ang-(1-7). Stimulation of Ang II also systemically alters metabolic profiles and modulates insulin sensitivity in the affected tissues [43]. Experimental models following the SARS-CoV epidemic have shown that Spike protein binding leads to a decrease in the expression of ACE2 receptors in the lungs, suggesting that lung damage may be mediated by higher Ang II levels compared to Ang-(1-7) [70]. Thus, the ACE2 receptor appears to play conflicting roles associated with the pathophysiology of SARS-CoV-2 infection: one where ACE2 facilitates disease as a SARS-CoV-2 binding site, and another where downregulation of ACE2 may contribute to severe traumatic lung injury after infection [71]. 
According to some authors, the ACE2 expression is decreased in patients with DM possibly due to glycation, which may explain the increased predisposition to severe lung damage and the manifestation of ARDS in patients with DM background of COVID-19 [68, 72]. Consequently, ACE2 overexpression will be counterproductive in patients with COVID-19, since SARSCoV-2 has been shown to use ACE2 as a receptor to enter the host's pneumocytes [73]. ACE2 expression is markedly increased in diabetic and hypertensive patients who receive ACEI or ARBs as an adaptive response to counter elevated Ang II and Ang I. It was previously thought that the use of ACE2-stimulating drugs promotes the penetration of SARS-CoV- 2 into pneumocytes and, therefore, can lead to more severe and fatal diseases [74]. To date, the use of RAAS inhibitors has been completely rehabilitated, since the expression of ACE2 during their use is one of the protective mechanisms in the functioning of RAAS. The virus binds to cells through its trimeric peak glycoprotein, which makes this protein a key target for potential therapy and diagnostics [73]. Like ACEl and ARBs, ibuprofen [75] and thiazolidinediones [76] can also lead to elevated ACE2 levels, which have previously raised some safety concerns in COVID-19 patients. Animal studies have shown that pioglitazone and liraglutide are also associated with ACE2 activation $[74,77]$. Unfortunately, none of the studies took into account the underlying therapy for COVID-19. In addition, a recently completed study found that critically ill patients with COVID-19 had a higher prevalence of hypokalemia due to renal failure. This can be explained by ACE2 suppression after viral penetration, which leads to a decrease in Ang II degradation, increased aldosterone secretion, and subsequent increased loss of potassium in the urine. It is assumed that early normalization of serum potassium levels is a predictor of a good prognosis in COVID-19 [78]. Thus, the ACE2 overexpression, although it promotes the penetration of SARS-CoV-2, still plays a protective role for the lung tissue, as well as for other organs and systems, since it prevents the start of a pathological cascade of systemic reactions caused by breakdown of the RAAS, leading to multiple organ dysfunction. DM has been associated with worse outcomes in COVID-19 patients, however, susceptibility to SARSCoV-2 infection is higher in people with decompensated DM. According to several studies, the prevalence of DM among those infected with the COVID-19 virus is about the same as in the general population $[79,80]$.

As previously established, ACE2 and dipeptidyl peptidase-4 (DPP-4) are receptors for the entry of the coronavirus. In recent publications, there has been extensive discussion regarding the possibility of DPP-4 being a receptor for COVID-19. In a series of recent studies, it has been suggested that DPP-4 is the main MERS-CoV receptor, but not SARS-CoV-2, that is, not the COVID-19 receptor [42]. The DPP4 enzyme is a type II transmembrane glycoprotein expressed in many tissues, including immune cells. DPP-4 is also known as CD26, a lymphocyte cell surface protein that plays an important role in the functioning of T cells [81]. J. Liu et al. in a study of the immune characteristics of COVID-19 showed that patients with severe illness had higher serum levels of IL-6, IL-10, IL-2 and $\gamma$-interferon and fewer neutrophils and T cells (especially CD8+T cells) than patients with a mild course of the disease, which indicates a large-scale cytokine storm in general and a T-cell storm in particular [82]. The increased $T$ cell activity is manifested by an increase in Th17 levels and high cytotoxicity of CD8+ T cells, which partly explains the severe immune damage to the lungs associated with COVID-19 infection. DPP-4/CD26 is present and active in the lungs and is constitutively expressed by lung fibroblasts, where it has a proliferative effect [83]. DPP-4/CD26 is also a marker of migration and functional activation of fibroblasts, including collagen synthesis and secretion of inflammatory cytokines [83]. Inflammatory lung diseases are characterized by high levels of DPP-4/CD26 expression, which can enhance the inflammatory response and the severity of lung injury [77, 84].

Although its functions are not yet fully understood, DPP-4 plays a major role in glucose and insulin metabolism. DPP-4 degrades incretins such as glucagon-like peptide 1 (GLP-1) and glucose-dependent insulinotropic polypeptide, which ultimately leads to decreased insulin secretion and impaired visceral adipose tissue metabolism. DPP-4 regulates postprandial glycemia through the degradation of GLP-1. DPP-4 expression is higher in visceral adipose tissue and is directly correlated with adipocyte inflammation and insulin resistance. DPP-4 also plays an important role in immune regulation by activating $T$ cells, CD86 expression and the NF-KB pathway. Since DPP-4 inhibitors are commonly used in the treatment of DM around the world, a number of studies have suggested the possible use of DPP-4 as a receptor for SARS-CoV-2 and, accordingly, the hypothetical possibility of potentiating the resource protective effect of DPP inhibitors against COVID-19 [85]. In April 2020 publication, D.J. Drucker postulates that GLP-1 levels and DPP-4 activity are regulated by infection and inflammation, and in turn DPP-4 inhibitors and GLP-1 receptor agonists can also modulate inflammation. The two receptor proteins of the coronavirus, ACE2 and DPP-4, are established transducers of metabolic signals and pathways that regulate inflammation, renal physiology, cardiovascular system, and glucose homeostasis. Thus, the available data currently do not confirm clinically significant changes in markers of immune function after the administration of DPP-4 inhibitors to people with or without T2D, on the basis of which it can be argued that DPP-4 is not a SARS-CoV-2 receptor and, accordingly, cannot serve as a launching pad for the disease, COVID-19 from MERS-CoV [86].

\section{THERAPEUTIC APPROACHES TO DIABETIC PATIENTS WITH COVID-19}

According to the American Diabetes Association (ADA), people with DM have a higher rate of complications and mortality from COVID-19 because this disease is inherently associated with a compromised immune response, making people with it more susceptible to infections. On the other hand, it is believed that hyperglycemia in patients with DM may be the cause of dysfunction of the immune response, which leads to an inability to control the spread of pathogens and makes patients with DM more susceptible to infections, which is fully consistent with the statement of R. Gupta that the management of DM provides, first of all, good glycemic control during the manifestation of COVID-19 [87]. Due to the rapid spread of COVID-19, there are serious discussions now on a number of important topics related to the optimal treatment of patients 
with DM during the COVID-19 pandemic, including the susceptibility to this new infection, the severity of complications, and the role of drugs used to control glycemia [7, 88, 89]. DM is associated with a poor prognosis in many viral infections, including coronavirus. The proposed mechanisms for this apparent association between COVID-19 and DM include numerous disorders up to and including complete breakdown of the innate immune system. In addition, ACEI and ARBs, widely used in people with DM are the link between COVID-19 and DM. ACEI/ARBs lead to upregulation of ACE2, which, as mentioned above, is constitutively expressed in the lungs, heart, intestines, kidneys, and vascular endothelium $[80,90]$. Current epidemiological data on COVID-19 do not support the hypothesis that patients with DM are at increased risk of infection compared with the general population [74, 80], and it is clear that DM, especially when it is poorly controlled, exposes patients to high the risk of death $[9,37,91]$. It should be emphasized once again that an extremely important element of pathogenesis is a molecule that plays the role of the SARSCoV-2 receptor, identified as ACE2 [26, 92]. Recently, it has been suggested that sodium-glucose cotransporter-2 inhibitors (SGLT-2i), glucagon like peptide-1 receptor agonists (GLP1RA), pioglitazone, and even insulin may overexpress the ACE2 receptor $[88,93]$, which increases the risk of more serious infections in diabetic patients. This problem is of great importance, as it is now argued that optimal glycemic control in DM is needed more than ever $[93,94]$. When the question of the possible induction of ACE2 expression was raised regarding the use of ACEl or ARBs, several scientific societies, as well as the European Medical Agency (EMA), explained that so far this is only a hypothesis coming from some in vitro studies and has not yet been confirmed by any clinical results according to the data in people affected by COVID-19, it is absolutely unjustified to stop using such drugs, which are very effective in saving lives, which was confirmed by the subsequent numerous recommendations for their safe use [95]. A number of recent publications argue that such recommendations urgently need to be adapted for the applied antihyperglycemic therapy [96]. However, some hypoglycemic drugs may have side effects when used [97]. Many researchers are now considering the possibility of revising the prescribed antihyperglycemic therapy for patients with DM and COVID-19. Insulin is a safe choice in most cases and remains the only therapy for people with T1D and can be considered an excellent alternative for people with T2D who have poor glycemic control. Although no direct effect on ACE2 has been reported, insulin treatment has been shown to attenuate renal ADAM-17 expression in diabetic Akita mice $[9,37,96]$. In normal physiology, ADAM-17 cleaves ACE2, thereby inactivating the enzyme. Whether this phenomenon is repeated in human pneumocytes is unknown. Metformin and sulfonylureas do not interact with ACE2 or ADAM-17 and can be safely continued in mild COVID-19 [98]. In contrast, recent publications have shown that pioglitazone activates ACE2 expression in insulin-sensitive tissues in rats and decreases ADAM-17 activity in human skeletal muscle [80, 99]. While it is extremely important to ensure that patients have their blood glucose monitored in an outpatient basis to prevent severe COVID-19 infection, there are also consider- ations regarding outpatient medication use [100, 101]. It is recommended to consider stopping metformin, especially if the patient has more severe symptoms and is at risk of dehydration, as this may increase the likelihood of lactic acidosis or liver damage $[102,103]$. SGLT-2i are also recommended to be withdrawn due to the risk of volume depletion and diabetic ketoacidosis in patients with COVID-19 [101, 104]. The risk of euglycemic DKA with SGLT-2i is present even a couple of days after drug withdrawal [104]. Patients should be monitored for early signs and symptoms of diabetic ketoacidosis, such as nausea, vomiting, or abdominal pain, as these can occur in patients with normal blood glucose levels. Some of the most common triggers of euglycemic diabetic ketoacidosis in patients taking SGLT-2i include vomiting, dehydration, cessation or reduction in insulin or insulin-secreting drugs, surgery, viral or bacterial infection, or decreased calorie intake [102]. You can continue to take GLP-1 receptor agonists and DPP-4 inhibitors. Patients should be advised to avoid dehydration and use regularly to prevent serious dehydration-related illnesses. Insulin therapy should not be discontinued and the patient should be monitored more regularly for blood glucose (every 2-4 hours). Insulin dose adjustment may be required [101, 105]. The effectiveness of both GLP-1 receptor agonists and SGLT-2 $i$ therapy for the prevention of CVD and kidney disease in patients with DM is well known [106], which is incredibly important for maintaining good functional activity of the cardiovascular and renal systems, especially during a pandemic. People with CVD or renal disease have a worse prognosis during COVID-19 [8], so it seems necessary to maintain the integrity and functionality of the renal and cardiovascular systems in people with DM who may be affected by COVID-19 infection. Although there is no specific data on the use of an SGLT-2i during COVID-19 infection, it is advisable not to take them in the acute phase of the disease due to the increased risk of dehydration and diabetic ketoacidosis [107, 108]. Inflammation plays a key role during SARS-CoV-2 infection [109]. DPP4 is expressed in many tissues, including the respiratory tract, which represents a potential target for reducing the severity of COVID-19 in patients with DM, as it is the target of incretin-based therapy, and this has opened a debate about whether DPP-4 inhibitors can currently used to treat people with T2D, be effective in patients with DM and SARS-CoV-2 [95]. Some authors have suggested that the potential anti-inflammatory role of DPP-4 inhibitors raises the question of whether DPP-4 modulation can help compensate for the cytokine-mediated acute respiratory complications of COVID-19 [110]. DPP-4 inhibitors are associated with a low risk of hypoglycemia and are relatively safe. DPP4 inhibitors added to basal insulin improve glycemic control without increasing the risk of hypoglycemia, even among hospitalized patients [111]. However, these drugs are of less therapeutic benefit in patients with severe COVID-19. Although patients with mild symptoms can continue to take DPP-4 inhibitors, they should be ruled out in acute severe illness and replaced with insulin. In addition, it should be emphasized that GLP-1 receptor analogs have exhibited significant anti-inflammatory and anti-adipogenic effects over the years, thereby reducing insulin resistance $[112,113]$. The effect of reducing inflammatory stress 
and peripheral insulin resistance by weakening association with macrophages through GLP-1 dependent signaling and regulating the polarization of $\mathrm{M} 1 / \mathrm{M} 2$ macrophages has been described with DPP4 inhibition and GLP-1 activation [114]. Similar data on influences on inflammation have also been reported for SGLT-2i [115] and pioglitazone [116]. GLP-1 receptor agonist therapy should probably be discontinued temporarily in patients with hemodynamic instability, renal and gastrointestinal dysfunction. Treatment with GLP-1 receptor agonists can cause gastrointestinal side effects with hypovolemia and regurgitation [117]. During a severe course of COVID-19, when using sulfonylurea preparations, it is difficult to control blood glucose levels. Therefore, in such patients, sulfonylurea preparations should be replaced with insulin. Thiazolidinediones, in particular pioglitazone, are a less favorable option for inpatient treatment of critically ill patients due to fluid retention and increasing systemic edema. They are also contraindicated in patients with hemodynamic instability, hepatic or cardiac dysfunction [118]. There is currently no direct evidence for against continuing statin use in patients with DM and COVID-19. There are preliminary reports of elevated levels of the liver and muscle enzymes associated with COVID-19, although severe liver disease or rhabdomyolysis is not common with coronavirus infection [119]. Therefore, personalized therapy for patients with DM and COVID-19 is now postulated, taking into account the indications for statin therapy, as well as possible drug interactions with antiviral drugs. Consequently, in anticipation of specific clinical data, a balance is certainly needed between the potential dangerous effects of certain drugs in the clinic, supported mainly by experimental data, and the proven effects of drugs on the cardiovascular and renal systems, as well as their anti-inflammatory potential [120].

Analyzing the clinical experience of treating people with DM during this pandemic, R. Pal and S.K. Bhadada emphasized that the antimalarial drug hydroxychloroquine has been used as prophylaxis against COVID-19 in many countries; however, in the case of concomitant administration of hydroxychloroquine with other antidiabetic drugs, the dose of concomitant therapy should be revised, especially in patients with a higher hypoglycemic risk [88]. Indeed, it has been known for over 30 years that hydroxychloroquine has a hypoglycemic effect that can provoke severe episodes of hypoglycemia. G.D. Smith et al. in 1987 described a significant improvement of glycemic parameters in a few patients with T2D who received hydroxychloroquine [121]. This discovery was then confirmed by A. Quatraro et al. in a study published in 1990 that described T2D treated with insulin or glibenclamide in combination with hydroxychloroquine for 6 months. The authors found a significant decrease in glycosylated hemoglobin - by $3.3 \%$ compared with placebo and a decrease in insulin doses by $30 \%$ [122]. At the moment, hydroxychloroquine at a dose of $400 \mathrm{mg}$ per day is approved in several countries as an additional third-line antidiabetic drug after metformin and sulfanylureas in people with T2D [97]. The drug works by raising the intracellular $\mathrm{pH}$, which inhibits the enzymatic degradation of insulin, which results in the recirculation of a significant part of the insulin in its active form. Consistent with its immunomodulatory properties, hydroxychloroquine is also able to reduce the secretion of pro-inflam- matory cytokines, especially TNF- $a$ and IL-6, thereby reducing insulin resistance. Interestingly, hydroxychloroquine is effective against SARS-CoV-2 in vitro and lowers viral load in COVID-19 patients. Mechanisms of action include disruption of binding between cellular ACE2 and the SARS-CoV-2 spike viral protein by increasing intracellular/endosomal $\mathrm{pH}$, as well as inhibiting antigen presentation, subsequent suppression of T cell activation and hypersecretion of proinflammatory cytokines, thereby contributing to the prevention of cytokine storm [106]. Although inflammation is associated with impaired glucose levels, the underlying mechanism of the hypoglycemic effect of hydroxychloroquine is still not fully understood [123]. Chloroquine has been reported to increase the $C$-peptide secretory response, potentially reflecting improved pancreatic $\beta$-cell function [124]. A decrease in intracellular insulin degradation and an increase in insulin accumulation have also been identified as possible effects of hydroxychloroquine in experimental models [125]. Given earlier reports of the effects of chloroquine/hydroxychloroquine on glucose metabolism, caution is advised when prescribing the drug to patients with DM and COVID-19. Adjustment of the dose of oral antidiabetic drugs and/or insulin may be necessary to prevent possible hypoglycemic events [126]. Antimalarial drugs chloroquine and hydroxychloroquine have been used for the treatment of SARSCoV-2 infection, despite their potential side effects $[127,128]$. The two main mechanisms of action of hydroxychloroquine are believed to be its restriction of viral protein breakdown at the ACE2 binding site and its anti-inflammatory and immunomodulatory properties [129]. Hydroxychloroquine also lowers blood glucose levels by increasing insulin sensitivity and improving pancreatic $\beta$-cell function [130], which made it possible to prescribe hydroxychloroquine as an antidiabetic drug in some countries [131]. Therefore, adjustments to pre-existing antidiabetic drugs may be required to avoid hypoglycemia in rare cases in diabetic patients taking hydroxychloroquine [132, $133,134]$. It should be noted that studies have shown conflicting results regarding the effectiveness of hydroxychloroquine in the treatment of patients with COVID-19. According to COVID-19 RISK and Treatments (CORIST) Collaboration, use of hydroxychloroquine in hospitalised COVID-19 patients is associated with reduced mortality $[135,136]$. More well-designed studies are needed to evaluate its therapeutic efficacy [137].

To date, there are no reliable investigations conducted in humans during the COVID-19 pandemic to study the use of antidiabetic drugs. Therefore, in the absence of compelling evidence-based benefits, many researchers believe it is impossible to prioritize antihyperglycemic drugs. Good glycemic control should be the goal, no matter what medications are used. So, in recent studies, it has been reliably established that hyperglycemia during hospitalization - regardless of diabetic status - is a key predictor of death and severity of COVID-19 among non-critical patients. The probability of death in people with abnormally high glucose level was more than twice higher than that of people with normal indices (41.4\% vs. $15.7 \%$ ). They also had an increased need for mechanical ventilation unit and an intensive care unit. These results provided a simple and practical way to stratify the risk of death in hospitalized COVID-19 patients [138]. 
Diabetic retinopathy and cardiomyopathy are contraindications for hydroxychloroquine use. Consequently, the antihyperglycemic effect of hydroxychloroquine deserves close study in further clinical studies in patients with DM against the background of coronavirus infection. Insulin is used overwhelmingly in hospitalized patients compared to other glucose lowering drugs. Also in hospitalized patients, the preferred strategy for the treatment of hyperglycemia is subcutaneous insulin therapy with basal or intermediate-acting insulin in conjunction with bolus insulin [139]. In these patients, less aggressive insulin regimens may be warranted to simply minimize glucosuria, dehydration, and electrolyte disturbances. Although there are no strong recommendations for an insulin regimen for glycemic control in critically ill patients, intravenous insulin infusions and short or rapid-acting insulin boluses can be used. When determining the insulin dosage, one should take into account the severity of the disease, nutritional status, concomitant medications and the tendency of glycemic fluctuations [140]. In T1D patients with COVID-19 and hyperglycemia, it is important to control blood glucose and ketone levels, maintain hydration, and continue insulin therapy. To date, recommendations have been developed for the treatment of infections in patients with $\mathrm{DM}$, and the same recommendations apply to patients who are also diagnosed with COVID-19. In general, diabetic patients, especially those whose disease is uncontrolled or poorly controlled, may be more susceptible to infections, possibly because hyperglycemia can reduce immunity. Glucose control is key, as good glycemic control can help reduce the risk and severity of infection. The ADA (American Diabetes Association) reported that in China, people with DM have higher rates of serious complications and deaths than people with the virus without it. However, there are several ways to reduce this risk. According to the ADA, "If DM is treated well, the risk of serious illness from COVID-19 is about the same as that of the general population". DM that is not properly treated can increase the risk of related complications, one of which may be heart failure, another condition identified by the CDC and $\mathrm{WHO}$ as posing a higher risk of serious complications from COVID-19. The ADA postulates that viral infections such as the new coronavirus increase inflammation, which also manifests when blood glucose levels exceed a target, further increasing the risk of complications. Obesity is a major risk factor for DM and appears to be an independent risk factor for severe illness in COVID-19. Thus, the incidence of severe illness is likely to be particularly high in regions and populations where both obesity and DM are prevalent. Since more severe hyperglycemia accompanies progression to severe pulmonary and systemic disease, better metabolic control with insulin infusion or other means may be protective. Complications of DM, including kidney, heart, and peripheral vascular disease, can be additional risk factors and require special attention. Several circulating markers of systemic inflammation are elevated in severe cases, suggesting possible molecular sites for intervention. Of particular interest is the observation that ACE2 expression is associated with DM and may be implicated in this viral infection, offering another starting point for research into the development of targeted interventions [141]. People with T1D and T2D have a higher risk of DKA when they contract a viral infection. If a patient with DM is in a state of DKA, it can make it difficult to prevent sepsis and septic shock, which, according to the ADA, "are some of the most serious complications that some people with COVID-19 face." ADA recommends that insulin should be given to severely ill patients with DM and COVID-19, and oral antidiabetic drugs such as metformin and SGLT2 inhibitors should be discontinued [137]. This is standard practice in critically ill patients. Metformin can increase the lactic acid levels, and SGLT2 inhibitors cause hypovolemia, inhibit fat metabolism, and potentiate acidosis. The introduction of analogs of GLP-1, which can cause regurgitation, and pioglitazone, the therapy with which is accompanied by hypervolemia, is also discontinued.

The anti-inflammatory and immunomodulatory effects of 3-hydroxy-3-methylglutaryl-CoA reductase inhibitors or statins suggest they may be useful for treating influenza and bacterial infections [142, 143]. A study in China found that statin use was associated with a lower risk of all-cause death and a favorable recovery profile in hospitalized COVID-19 patients [144]. Statin therapy is currently actively used in patients with DM against the background of coronavirus infection. Evidence suggests COVID-19 significantly increases the likelihood of thromboembolic events, which are the predominant cause of death [145, $146,147]$. The first evidence of abnormal coagulation parameters associated with COVID-19 appeared in early reports from China. For example, the baseline characteristics of the first 99 patients admitted to Wuhan showed that $6 \%$ had increased clotting time, 5\% had increased prothrombin levels, and 36\% had increased D-dimer levels [145]. Another study from China showed that in patients who died from COVID-19, the level of D-dimer and fibrin breakdown products was statistically significantly increased [148]. In this study, which involved middle-aged Chinese patients with COVID-19, more than $71 \%$ of the deaths met the criteria for intravascular coagulation syndrome. It should be noted that 11 studies to date have found high rates of venous thromboembolism in patients diagnosed with COVID-19 [149].

Coagulopathy associated with COVID-19 ranges from mild changes in laboratory findings to disseminated intravascular coagulation with a predominant thrombotic and/or multiple organ failure phenotype 148 . A deep inflammatory reaction due to SARS-CoV-2 infection leads to the development of DIC syndrome [147]. Vascular endothelial dysfunction appears to contribute to the pathophysiology of microcirculatory changes in patients with SARS-CoV-2 infection [150]. Importantly, SARS-CoV-2 can penetrate endothelial cells and infect them through the ACE2 receptor, while viral replication causes infiltration of inflammatory cells, endothelial cell apoptosis and prothrombotic effects of microvessels [151, 152]. Pathological studies of patients who died from SARS-CoV-2 infection showed the presence of viral inclusions in endothelial cells and sequestered infiltration of mononuclear and polymorphonuclear cells with evidence of endothelial apoptosis [152]. Thus, the evidence suggests that increased release of clotting factors and dysregulation and destruction of endothelial cells are the main mechanisms of increased thromboembolism in patients with COVID-19 [153]. Endothelial dysfunction may also explain reports of cerebrovascular complications in younger patients 
and in patients with myocardial ischemia and/or thromboembolic complications [152]. Several publications report an increased risk of thromboembolism in diabetic patients outside the specific situation of SARS-CoV-2 infection. For example, a population-based study showed that patients with T2D have an increased risk of venous thromboembolism compared to controls (relative risk 1.44, 95\% confidence interval 1.27-1.63) [154]. In addition, the risk of pulmonary thromboembolism was higher in patients with T2D than in patients in the control group (relative risk 1.52, 95\% confidence interval 1.22-1.90) [154]. Another study showed that the incidence of deep vein thrombosis after total knee replacement was statistically significantly higher in patients with DM than in patients without it [155]. DM was also found to be associated with a more than doubled risk of ulceration after deep vein thrombosis $[156,157]$. Thus, patients with DM are already at high risk for thromboembolic events or stroke [158]. The exact molecular and cellular mechanisms underlying higher blood clotting in COVID-19 patients are currently poorly understood, and routine prophylaxis does not seem to be always effective in preventing thromboembolism [159]. However, anticoagulant therapy (low molecular weight heparin) gives better prognosis in patients with severe COVID-19 at high risk of thromboembolism, such as those with elevated D-dimer levels [160]. Thus, it is necessary to initiate anticoagulant therapy for hospitalized patients with moderate to severe COVID-19 disease.

Although evidence supporting any direct effect of GLP-1 analogs on thromboembolic risk is limited, several animal studies have shown that treatment with GLP-1 analogs inhibits atheroma formation and stabilizes plaque in the carotid arteries and aortic arches [161, 162]. In vitro administration of GLP-1 reduces the expression of matrix metalloproteinases 2 and MCP1 and translocation of NF-KB-p65, which is associated with a high risk of thromboembolism [161]. A study of cardiovascular outcomes showed that therapy with dulaglutide, a long-acting GLP-1 analogue, reduced the incidence of stroke in patients with T2D [163]. Thus, patients with DM should choose antidiabetic drugs that reduce the risk of thromboembolic events.

To date, no SARS-CoV-2 drug or vaccine has been formally approved for the treatment of COVID-19 [164]. Numerous clinical trials are underway to assess the safety and efficacy of possible drugs, including remdesivir, tocilizumab, lopinavir/ritonavir, ribavirin, interferon, chloroquinine, and others, which have been widely used in all countries since the start of the pandemic [165]. While there is no reliable evidence for any drug of specific antiviral efficacy or clinical results in the treatment of COVID-19, some drugs are used based on limited clinical data or are in clinical trials. The safety concerns of drugs must be weighed against their relative benefits. At the moment, there are some problems with some of these drugs used in patients with DM.

\section{COVID-19 THERAPY IN PATIENTS WITH DIABETES MELLITUS}

The global pandemic COVID-19 has led to the search for effective means of preventing and treating SARS-CoV-2 infection [166]. More than 1,800 clinical trials are ongoing to study the immune response to infection now. However, the effectiveness of most drugs has not yet been proven. Cytokine release syndrome ("cytokine storm") is considered to be central to the pathogenesis of the rapid deterioration and precipitation of multiple organ dysfunction in COVID-19 patients, and therefore immunomodulatory agents are postulated to be highly effective. Camostat mesylate is a serine protease inhibitor that is being investigated for its ability to inhibit viral entry as it inhibits the transmembrane protease serine 2 (TMPRSS2), which facilitates viral entry into the host cell [167]. Treatment with camostat mesylate has been reported to reduce the incidence of new-onset DM in patients with chronic pancreatitis [168]. This drug has improved glycemia and insulin resistance and reduced lipid accumulation on animal models $[169,170]$.

Chloroquine/hydroxychloroquine is one of the pharmacological options of relevance for patients with DM. Widely used for the treatment of malaria and autoimmune diseases, chloroquine is also considered a broad-spectrum antiviral drug. Several studies have reported that hydroxychloroquine improves glycemic control in decompensated diabetic patients refractory to basic antidiabetic therapy [123]. Hypoglycemia is a known adverse effect of hydroxychloroquine therapy. The following mechanisms of chloroquine/hydroxychloroquine antihyperglycemic activity have been established: a decrease in intracellular insulin degradation, an increase in insulin-mediated glucose transport and insulin secretion, and an increase in insulin sensitivity [123]. Therefore, according to many researchers, special care should be taken when using these drugs simultaneously with other glucose lowering agents, which may necessitate a dose reduction [171]. An immunosuppressant approved for the treatment of autoimmune diseases, including severe rheumatoid arthritis, tocilizumab, or acterma, is aimed at suppressing the hypersecretion of IL- 6 , which is one of the links in the pathophysiological cycle of the cytokine storm in diabetic patients with COVID-19. Systemic corticosteroids are well known to cause hyperglycemia, primarily through increased postprandial glucose levels, insulin resistance, and pancreatic $\beta$-cell dysfunction, which often require initiation of insulin therapy [172]. Despite this concern, intravenous dexamethasone therapy statistically significantly increased the number of non-ventilated days in patients with severe ARDS and COVID-19 [173, 174]. In addition, a meta-analysis of clinical trials showed that systemic corticosteroid therapy is associated with reduced short-term all-cause mortality in patients with severe COVID-19 [175]. Treatment with hydrocortisone according to different regimens also showed a tendency towards better treatment of these patients in hospital [176]. However, another study failed to prove any beneficial effect of low-dose hydrocortisone in treating COVID-19 patients [177]. Less than optimal dosage may be the reason for these disappointing results. Further research is needed to elucidate the effect of pharmacological treatments for COVID-19 on glucose metabolism in patients with DM. Severe lung tissue damage followed by ARDS is in part due to a potent immune response. Although corticosteroids suppress pneumonia, they also suppress immunity at the same time [178]. Given the systemic hyperglycemic effect and the serious effect of these drugs on the immune response [179], special care should be taken in patients with DM. Corticosteroids are widely used today in the treatment of severe ARDS caused by viral pneumonia and have proven to be 
the drug of choice for critically ill patients [180]. Since hyperglycemia may increase with the use of these drugs in patients with DM, it may be necessary to escalate insulin therapy [171]. The overall goal of antiviral drugs is to stop the replication of new viral RNA, preventing infected cells from COVID-19 patients from becoming "production sites" for duplicating new virions. Nucleotide analogs accomplish this by incorporating a base into the replication strand from which viral RNA polymerase cannot efficiently duplicate.

Today, ivermectin, an antiparasitic drug that has demonstrated antiviral activity against SARS-COV-2, is recommended for a fairly widespread use. Its early administration can lower viral load, reduce disease severity, and the risk of further spread of infection [181].

The drug remdesivir was originally tested in patients with Ebola and is now being tested for efficacy in the treatment of COVID-19. Earlier, the Food and Drug Administration (FDA, USA) approved the use of remdesivir for patients with extremely severe COVID-19. Remdesivir, an inhibitor of a nucleotide analogue of RNA-dependent RNA polymerase, increased glycemia and increased insulin resistance in mice fed a high-fat diet [182]. In contrast, increases in blood glucose were similar between remdesivir and placebo groups in two randomized control trials with multiethnic groups and patients from China $[137,183,184]$. Thus, more evidence is needed to elucidate its effect on glucose metabolism. Currently, 5 clinical trials in China and the United States are assessing whether remdesivir can reduce the risk of complications or shorten the duration of the disease in patients with COVID-19. The FDA has now authorized the emergency use of remdesivir, which, although it does not reduce mortality, significantly shortens the course of the disease in patients with less severe disease [185]. Further studies are underway to assess the efficacy of remdesevir in patients with COVID-19 and DM, as well as in patients with multimorbidity. Antiviral drugs - protease inhibitors interfere with the formation of new virions by infected cells by binding and inactivating viral proteases to stop viral replication. A screening study has shown that treatment with lopinavir-ritonavir (Abbvie) and ribavirin reduced mortality and ARDS compared to treatment with ribavirin alone [186]. Ritonavir is added to lopinavir as a pharmacokinetic enhancer [187]. Ritonavir is a potent inhibitor of cytochrome CYP 3A4, an enzyme that inactivates lopinavir. Protease inhibitors, lopinavir and ritonavir have been reported to increase the risk of hyperglycemia and onset of newly diagnosed DM, decompensate pre-existing DM, and develop diabetic ketoacidosis [188, 189, 190, 191, 192].

Another problem associated with protease inhibitors is pharmacological interactions with co-administered antihyperglycemic drugs. Therefore, frequent monitoring of blood glucose levels and dosage adjustments are recommended for patients taking these drug combinations. Currently, clinical studies of the efficacy of drugs in patients with coronavirus infection are ongoing [192]. Recent publications have shown that the initial peak priming of the TMPRSS2 spike protein is required for the penetration and spread of COVID-19 through interaction with the ACE2 receptor [41]. Camostat mesylate is a serine protease inhibitor that is being investigated for its ability to inhibit viral entry as it inhibits TMPRSS2, which facilitates viral entry into the host cell [41]. Treatment with camostat mesylate has been reported to reduce the incidence of new-onset DM in patients with chronic pancreatitis [168]. It has been shown that the TMPRSS2 inhibitor camostat mesylate, approved in Japan for the treatment of certain diseases, blocks the activity of TMPRSS2 [193] and may serve as a candidate for drugs against COVID-19. The creation of a vaccine is aimed at creating long-term immunity. Unlike DNA vaccines, mRNA vaccines can integrate into the host genome, reducing the risk of mutations [194]. The mRNA-1273 vaccine is a new mRNA-based lipid nanoparticle encapsulated, which encodes a form of the spike protein stabilized before prefusion [195]. The prefusion form is identified as the spatial conformation of the spike protein before it binds to ACE2. Antibodies against the prefusion form can prevent the penetration of the virus and also reduce the spread of virions. The macrolide antibiotic azithromycin, used to inhibit bacterial protein synthesis by binding to a subunit of the bacterial ribosome. It is also used to treat exacerbations of chronic obstructive pulmonary disease and reactive airways disease. This second use may reflect the modulating effect of azithromycin on immune cells. It reduces the release of respiratory syncytial virus by decreasing interferon signaling in vivo and inhibits the release of proinflammatory cytokines in airway smooth muscle and epithelial cells [196]. In a prospective study conducted in France with 22 patients, it was noted that a combination of 600 mg hydroxychloroquine and azithromycin (500 mg on the first day, then $250 \mathrm{mg}$ every day for the next 4 days) reduced viral load more effectively than hydroxychloroquine alone [197]. Besides the classic RAAS, alternative components, including ACE2, Ang-(1-7), Ang-(1-9), and the Mas receptor, may be involved in the entry and progression of SARS-CoV-2. Many international medical communities recommend continuing to take RAAS inhibitors because there is no proven evidence of harm when used in the context of DM and COVID-19. Previously, many researchers have hypothesized that the use of ACEI and ARBs increases the susceptibility to COVID-19, and it has been hypothesized that the ACE2 receptor is blocked or that COVID-19 does not bind to them by other means as an innovative approach that could be used to create a new drug, which should reduce mortality among those affected by the virus. Other authors have suggested that CVD, not immunodeficiency, are the most important risk factors for COVID-19. Patients with CVD appear to be at a higher risk of developing COVID-19 infection. One of the possible reasons may be as follows: patients with concomitant diseases such as arterial hypertension, T2D, cardiac and renal pathology may be indicative of ACEI and ARBs. Is there a connection between these observations? Is the expression of ACE2 receptors in viral target cells increased by the use of ACEI and ARBs and, therefore, is the risk of severe disease in humans higher? If this were the case, it would be possible to reduce the risk of death from COVID-19 in many patients by temporarily replacing these drugs. It is now firmly established that the use of RAAS inhibitors has a powerful protective effect on the lung tissue [137].

Currently, convalescent plasma means pooled plasma or immunoglobulins obtained from patients who have been infected and then cured. In ten patients seropositive for SARSCoV-2 and hypoxic, but not intubated, a single dose of $200 \mathrm{ml}$ 
of convalescent plasma resulted in a marked decrease in viral load and improved oxygenation [198]. Currently, convalescent plasma is widely used to treat patients with COVID-19. To date, there is no data on the optimal treatment of patients with DM infected with SARS-CoV-2, as well as patients with COVID-19 who develop glycemic decompensation. None of the drugs presented proved to be the dominant therapeutic strategy for the treatment of COVID-19, and at the moment the therapeutic breakthrough has been achieved only with the use of dexamethasone. Close monitoring of glucose levels and analysis of drug interactions can improve clinical symptoms and reduce the risk of adverse outcomes. Individual therapeutic strategies and optimal glucose control goals should be formulated based on the severity of the disease, the presence of comorbidities and complications associated with DM, taking into account the age of the patients and the presence of other aggravating factors. It has been proven that coronavirus infection has a huge impact on the treatment of DM exacerbates inflammation and alters the response of the immune system, which leads to difficulties in glycemic control. SARS-CoV-2 infection also increases the risk of thromboembolism and is more likely to cause cardiorespiratory failure in diabetic patients compared to non-diabetic patients. All of these mechanisms are now believed to contribute to the poor prognosis of patients with DM and COVID-19. During the COVID-19 pandemic, strict glycemic control and management of cardiovascular risk factors are critical for diabetic patients. Medications used for both DM and cardiovascular disease should be adjusted accordingly for people at high risk for SARS-CoV-2 [173, 174]. Based on these results, combined treatment with these two agents may be more beneficial than either of them alone. However, it should be borne in mind that the effectiveness of dexamethasone in the treatment of COVID-19 has been proven in well-designed randomized control trials such as the RECOVERY study, whereas no such conclusive randomized control trial has been conducted for hydroxychloroquine [173].

\section{CONCLUSION}

The global COVID-19 pandemic poses a significant health hazard, especially for patients with DM. A specific therapy is under development, unlike the COVID-19 vaccine. The optimal management strategy for these patients, such as the choice of hypoglycemic, antihypertensive and lipid-lowering drugs, is an important topic for current and future research. DM and other comorbidities are important predictors of severe course and high mortality in patients with COVID-19 [199]. Further clinical research is needed to provide a better understanding of the pathophysiological mechanisms underlying the link between COVID-19 and DM in order to achieve effective therapeutic breakthroughs in both treatment strategies and drug strategies aimed at preventing coronavirus infection in diabetic patients.

\section{REFERENCES/ЛITEPATYPA}

\section{Rothan, H.A., Byrareddy, S.N.}

"The epidemiology and pathogenesis of coronavirus disease (COVID-19)

outbreak."J Autoimmun 109 (2020): 102433

2. Ugwueze, C.V., Ezeokpo, B.C., Nnolim B.I., et al.

"COVID-19 and diabetes mellitus: The link and clinical implications." Dubai Diabetes Endocrinol I 26 (2020): 69-77.

3. Poutanen, S.M.

"Etiologic agents of infectious diseases." In: Long SS, editor. Principles and practice of paediatric infectious diseases. 4th ed. (2012): 1547-712.

4. Huang, C., Wang Y., Li X., et al.

"Clinical features of patients infected with 2019 novel coronavirus in Wuhan,

China."Lancet 395.10223 (2020): 497-506.

World Health Organization.

"Naming the coronavirus disease (COVID-19) and the virus that causes it 2020. [Online]. Available from: [https://www.who.int/emergencies/diseases/novelcoronavirus-2019/technical-quidance/naming-the-coronavirus-disease-

(covid-2019)-and-the-virus-that-causes-it], last accessed Feb 22, 2021.

6. Wu, Z., McGoogan, J.M.

"Characteristics of and important lessons from the coronavirus disease 2019

(COVID-19) outbreak in China: summary of a report of 72314 cases from the Chines

Center for Disease Control and Prevention." JAMA 323.13 (2020): 1239-42.

Guan, W. Ni, Z., Hu, Yu., et al.

"Clinical characteristics of coronavirus disease 2019 in China." N Engl J Med 382

(2020):1708-20.

8. Zhou, F., Yu, T., Du, R., et al.

"Clinical course and risk factors for mortality of adult inpatients with COVID-19

in Wuhan, China: a retrospective cohort study."Lancet 395.10229 (2020):

1054-62.

9. Yang, J., Zheng, Y., Gou, X., et al.

"Prevalence of comorbidities and its effects in patients infected with SARSCoV-2: a systematic review and meta-analysis." Int J Infect Dis 94 (2020):

91-5.

10. Wan, Y., Shang, J., Graham, R., et al.

"Receptor recognition by novel coronavirus from Wuhan: an analysis based on decade-long structural studies of SARS." JVirol 94.7 (2020): e00127-20.

11. Hulswit, R.J., de Haan, C.A., Bosch, B.J.

"Coronavirus spike protein and tropism changes." AdV Virus Res 96 (2016): 29-57.

12. Fernandez, C., Rysä, J., Almgren, P., et al.

"Plasma levels of the proprotein convertase furin and incidence of diabetes and mortality."J Intern Med 284.4 (2018): 377-87.

13. Guo, Y., Cao, Q., Hong, Z.

"The origin, transmission, and clinical therapies on corona virus disease 2019

(COVID-19) outbreak-an update on the status."Mil Med Res 7.1 (2020): 11.
14. World Health Organization.

Diabetes [Online]. Available from: [https://www.who.int/health-topics/ diabetes], last accessed Feb 22, 2021.

15. American Diabetes Association.

"Standards of Medical care in diabetes." Diabetes Care 2 Suppl 1 (2021).

16. Yang, P., Feng, J., Peng, Q., et al.

"Advanced glycation end products: potential mechanism and therapeutic target in cardiovascular complications under diabetes." Oxid Med Cell Longev (2019):

9570616. DOI: 10.1155/2019/9570616

17. Williams, R., Karuranga, S., Malanda, B., et al.

"Global and regional estimates and projections of diabetes-related health expenditure: Results from the International Diabetes Federation Diabetes Atlas,

9th edition." Diabetes Res Clin Pract 162 (2020): 108072

18. Pearson-Stuttard, J. Blundell, S. Harris T et al.

"Diabetes and infection: assessing the association with glycaemic control in

population-based studies." Lancet Diabetes Endocrinol 4.2 (2016): 148-58.

19. McDonald, H.I. Nitsch, D., Millett, E.R., et al.

"New estimates of the burden of acute community-acquired infections among older people with diabetes mellitus: a retrospective cohort study using linked electronic health records." Diabet Med 31.5 (2014): 606-14.

20. Li, S., Wang, J., Zhang, B., et al.

"Diabetes mellitus and cause-specific mortality: a population-based study." Diabetes Metab J 43.3 (2019): 319-41.

21. Knapp, S.

"Diabetes and infection: is there a link? - A mini-review." Gerontology 59.2 (2013): 99-104.

22. Schoen, K., Horvat, N., Guerreiro, N.F.C., et al.

"Spectrum of clinical and radiographic findings in patients with diagnosis of H1N1 and correlation with clinical severity." BMC Infect Dis 19.1 (2019): 964.

23. Yang, J..., Feng, Y., Yuan, M.Y., et al.

"Plasma glucose levels and diabetes are independent predictors for mortality and morbidity in patients with SARS." Diabet Med 23.6 (2006): 623-8.

24. Banik, G.R., Alqahtani, A.S., Booy, R., Rashid, H.

"Risk factors for severity and mortality in patients with MERS-CoV: Analysis of publicly available data from Saudi Arabia."Virol Sin 31.1 (2016): 81-4.

25. Onder, G., Rezza, G., Brusaferro, S.

"Case-fatality rate and characteristics of patients dying in relation to COVID-19 in Italy." JAMA 323.18 (2020): 1775-6.

26. Pal, R., Bhansali, A.

"COVID-19, diabetes mellitus and ACE2: The conundrum." Diabetes Res Clin Pract 162 (2020): 108132.

27. Jafar, N., Edriss, H., Nugent, K.

"The effect of short-term hyperglycemia on the innate immune system." Am Med Sci 351.2 (2016): 201-11.
28. Geerlings, S.E., Hoepelman, A.I

"Immune dysfunction in patients with diabetes mellitus (DM)." FEMS Immunol Med Microbiol 26.3-4 (1999): 259-65.

29. Petrie, J.R., Guzik, T.J., Touyz, R.M.

"Diabetes, hypertension, and cardiovascular disease: clinical insights and vascular mechanisms." Can J Cardiol 34.5 (2018): 575-84.

30. Ilyas, R., Wallis, R., Soilleux, E.J., et al.

"High glucose disrupts oligosaccharide recognition function via competitive inhibition: a potential mechanism for immune dysrequlation in diabetes

mellitus." Immunobiology 216.1-2 (2011): 126-31.

31. Ranganath Muniyappa, Sriram Gubbi.

"COVID-19 pandemic, coronaviruses, and diabetes mellitus." Am J Physiol Endocrinol Metab 318 (2020): E736-41.

32. Li, X.C., Zhang, J., Zhuo, J.L.

"The vasoprotective axes of the renin-angiotensin system: physiological relevance and therapeutic implications in cardiovascular, hypertensive and kidney diseases." Pharmacol Res 125 Pt A (2017): 21-38.

33. Lambert, D.W. Yarski, M. Warner FJ, et al.

"Tumor necrosis factor-a convertase (ADAM17) mediates regulated

ectodomain shedding of severe acute respiratory syndrome-coronavirus

(SARS-COV) receptor, angiotensin-converting enzyme-2 (ACE2)."J Biol Chem 280.34 (2005): $30113-9$

34. Du, L., He, Y., Zhou, Y., et al.

"The spike protein of SARS-CoV: a target for vaccine and therapeutic development." Nat Rev Microbiol 7.3 (2009): 226-36.

35. Palau, V., Riera, M. Soler, M.J.

"ADAM17 inhibition may exert a protective effect on COVID-19." Nephrol Dial Transplant $35.6(2020): 1-2$

36. Cesaro, A., Abakar-Mahamat, A., Brest, P., et al.

"Differential expression and regulation of ADAM17 and TIMP3 in acute inflamed intestinal epithelia." Am J Physiol Gastrointest Liver Physiol 296.6 (2009): 61332-43.

37. Salem, E.S., Grobe, N., Elased, K.M.

"Insul in treatment attenuates renal ADAM17 and ACE2 shedding in diabetic Akita mice." Am J Physiol Renal Physiol 306.6 (2014): F629-39.

38. Heurich, A., Hofmann-Winkler, H., Gierer, S., et al.

"TMPRSS2 and ADAM17 cleave ACE2 differentially and only proteolysis by TMPRSS2 augments entry driven by the severe acute respiratory syndrome coronavirus spike protein."J Virol 88.2 (2014): 1293-307.

39. Letko, M., Marzi, A., Munster, V.

"Functional assessment of cell entry and receptor usage for SARS-COV-2 and other lineage B betacoronaviruses." Nat Microbiol 5.4 (2020): 562-9.

40. Li, W., Moore, M.J., Vasilieva, N., et al.

"Angiotensin-converting enzyme 2 is a functional receptor for the SARS coronavirus." Nature 426.6965 (2003): 450-4. 
41. Hoffmann, M., Kleine-Weber, H., Schroeder, S., et al.

"SARS-COV-2 cell entry depends on ACE2 and TMPRSS2 and is blocked by a

clinically proven protease inhibitor." Cell 181.2 (2020): 271-80.

42. Song, Z., XU, Y., Bao, L., et al.

"From SARS to MERS, Thrusting coronaviruses into the spotlight."Viruses 11.1

(2019): E59.

43. Gheblawi, M., Wang, K., Viveiros, A., et al.

"Angiotensin-converting enzyme 2: SARS-CoV-2 receptor and regulator

of the renin-angiotensin system. Celebrating the 20th anniversary of the

discovery of ACE2." Circ Res 126.10 (2020): 1456-74.

44. Yang, J.K., Lin, S.S., Ji, X.J., Guo, L.M.

"Binding of SARS coronavirus to its receptor damages islets and causes acute

diabetes."Acta Diabetol 47.3 (2010): 193-9.

45. Tucker, M.E.

"ESC says continue hypertension meds despite COVID-19 concern."

Medscape [0nline] (2020). Available from: [https://www.medscape.com/

viewarticle/926838], last accessed Feb 22, 2021.

46. Zheng, Y.Y., Ma, Y.T., Zhang, J.Y., Xie, X

"COVID-19 and the cardiovascular system." Nat Rev Cardiol 17.5 (2020): 259-60.

47. Gurwitz, D.

"Angiotensin receptor blockers as tentative SARS-CoV-2 therapeutics." Drug

Dev Res (2020).

48. Hussain, A., Bhowmik, B., do Vale Moreira, N.C.

"COVID-19 and diabetes: Knowledge in progress." Diabetes Res Clin Pract 162 (2020): 108142.

49. Vickers, C, Hales, P. Kaushik, V, et al.

"Hydrolysis of biological peptides by human angiotensin-converting enzyme-related carboxypeptidase." Jiol Chem 277 (2002): 14838-43.

50. Benter, I.F., Yousif, M.H., Dhaunsi, G.S., et al.

"Angiotensin-(1-7) prevents activation of NADPH oxidase and renal vascular dysfunction in diabetic hypertensive rats." Am J Nephrol 28 (2008): 25-33.

51. El-Hashim, A.Z., Renno, W.M., Raghupathy, R., et al.

"Angiotensin-(1-7) inhibits allergic inflammation, via the MAS1 receptor,

through suppression of ERK1/2- and NF-kBdependent pathways."Br J

Pharmacol 166 (2012): 1964-76.

52. Santos, R.A.

"Angiotensin-(1-7)". Hypertension 63.6 (2014): 1138-47.

53. Santos, R.A., Simoes e Silva, A.C., Maric, C., et al

"Angiotensin-(1-7) is an endogenous ligand for the G proteincoupled

receptor Mas." Proc Natl Acad Sci USA 100.14 (2003): 8258-63.

54. Chamsi-Pasha, M.A., Shao, Z., Tang, W.H.

"Angiotensin-converting enzyme 2 as a therapeutic target for heart failure."

Curr Heart Fail Rep 11.1 (2014): 58-63.

55. Rice, G.I., Jones, A.L., Grant, P.J., et al.

"Circulating activities of angiotensin-converting enzyme, its homolog

angiotensin-converting enzyme 2, and neprilysin in a family study."

Hypertension 48.5 (2006): 914-20.

56. Anguiano, L., Riera, M., Pascual, J., et al.

"Circulating angiotensin-converting enzyme 2 activity in patients with

chronic kidney disease without previous history of cardiovascular disease."

Nephrol Dial Transplant 30.7 (2015): 1176-85.

57. Gilbert, A., Liu, J., Cheng, G., et al.

"A review of urinary angiotensin converting enzyme 2 in diabetes and

diabetic nephropathy." Biochem Med 29.1 (2019): 010501

58. Benigni, A., Cassis, P., Remuzzi, G.

"Angiotensin II revisited: New roles in inflammation, immunology and aging." EMBO Mol Med 27 (2010): 247-57.

59. Swirski, F.K., Nahrendorf, M., Etzrodt, M., et al.

"Identification of splenic reservoir monocytes and their deployment to

inflammatory sites." Science 325.5940 (2009): 612-6.

60. Thomas, M.C., Pickering, R.J., Tsorotes, D., et al.

"Genetic Ace2 deficiency accentuates vascular inflammation and

atherosclerosis in the ApoE knockout mouse." Circ Res 107.7 (2010): 888-97.

61. Alghamri, M.S., Weir, N.M., Anstadt, M.P., et al.

"Enhanced angiotensin II-induced cardiac and aortic remodeling in ACE2

knockout mice." J Cardiovasc Pharmacol Ther 18.2 (2013): 138-51.

62. Rodrigues, P. R. Rocha, N.P. Miranda, A.S, et al.

"The anti-inflammatory potential of ACE2/angiotensin-(1-7)/mas receptor

axis: Evidence from basic and clinical research." Curr Drug Targets 18.11

(2017): 1301-13.

63. Bineshfar, N., Mirahmadi, A., Karbasian, F., et al.

"Acute pancreatitis as a possible unusual manifestation of COVID-19 in

children." Case Rep Pediatr 2021 (2021): 6616211.

64. Agarwal, S., Agarwal, S. K

"Endocrine changes in SARS-CoV-2 patients and lessons from SARS-CoV."

Postgrad Med J 96.1137 (2020): 412-6.

65. Xiao, L., Sakagami, H., Miwa, N.

"ACE2: The key molecule for understanding the pathophysiology of severe

and critical conditions of COVID-19: demon or angel?"Viruses 12 (2020): 491.

66. Hsueh, W.A., Wyne K.

"Renin-angiotensin-aldosterone system in diabetes and hypertension." J Clin Hypertens 13.4 (2011): 224-37.

67. Munger, M.A.

"Use of angiotensin receptor blockers in cardiovascular protection: Current evidence and future directions." P T 36.1 (2011): 22-40

68. Tikellis, C., Thomas, M.C.

"Angiotensin-converting enzyme 2 (ACE2) is a key modulator of the renin

angiotensin system in health and disease." Int J Pept 2012 (2012): 256294.
69. Imai, Y., Kuba, K., Rao, S., et al.

"Angiotensin -converting enzyme 2 protects from severe acute lung failure."

Nature 436 (2005): 112-6

70. Kuba, K., Imai, Y., Rao, S., et al.

"A crucial role of angiotensin converting enzyme 2 (ACE2) in SARS

coronavirus-induced lung injury." Nat Med 11.8 (2005): 875-9.

71. AlGhatrif, M., Cingolani, O., Lakatta, E.G.

"The dilemma of coronavirus disease 2019, aging, and cardiovascular disease: Insights from cardiovascular aging science." JAMA Cardiol 5.7 (2020): 747-8.

72. Wu, C., Chen, X., Cai, Y., et al.

"Risk factors associated with acute respiratory distress syndrome and death in patients with coronavirus disease 2019 pneumonia in Wuhan, China." JAMA Intern Med 180.7 (2020): 934-43.

73. Wrapp, D. Wang, N., Corbett, K.S., et al.

"Cryo-EM structure of the 2019-nCoV spike in the prefusion conformation."

Science 367.6483 (2020): 1260-3.

74. Fang, L., Karakiulakis, G., Roth, M.

"Are patients with hypertension and diabetes mellitus at increased risk for

COVID-19 infection?"Lancet Respir Med 8.4 (2020): e21

75. Qiao, W., Wang, C., Chen, B., et al.

"Ibuprofen attenuates cardiac fibrosis in streptozotocin-induced diabetic rats." Cardiology 131.2 (2015): 97-106.

76. Zhang, W. Li, C. Liu, B., et al.

"Pioglitazone upregulates hepatic angiotensin converting enzyme 2

expression in rats with steatohepatitis." Ann Hepatol 12.6 (2013): 892-900.

77. Shiobara, T., Chibana, K., Watanabe, T., et al.

"Dipeptidyl peptidase-4 is highly expressed in bronchial epithelial cells of

untreated asthma and it increases cell proliferation along with fibronectin

production in airway constitutive cells." Respir Res 17 (2016): 28.

78. Dong, C., Li, X., Song Qifa, et al.

"Hypokalemia and clinical implications in patients with coronavirus disease

2019 (COVID-19)." [Online]. Infectious Diseases (except HIV/AIDS) (2020).

DOI: $10.1101 / 2020.02 .27 .20028530$

79. Li, B., Yang. J., Zhao, F. et al.

"Prevalence and impact of cardiovascular metabolic diseases on COVID-19 in

China." Clin Res Cardiol 109.5 (2020): 531-8.

80. Fadini, G.P., Morieri, M.L., Longato, E., Avogaro, A.

"Prevalence and impact of diabetes among people infected with SARS-

CoV-2." J Endocrinol Invest 43.6 (2020): 867-9.

81. Pinheiro, M., Pinheiro, J., Pinheiro, F., et al

"Editorial - COVID-19 pandemic: is it time to learn about DPP-4/CD26?" Cell

8 (2020): e2835.

82. Liu, J., Li, S., Liu, J., et al.

"Longitudinal characteristics of lymphocyte responses and cytokine profiles in the peripheral blood of SARS-CoV-2 infected patients." EBioMedicine 55

(2020): 102763

83. Anderluh, M., Kocic, G., Tomovic, K., etal.

"DPP-4 inhibition: A novel therapeutic approach to the treatment of

pulmonary hypertension?" Pharmacol Ther 201 (2019): 1-7.

84. Nieto-Fontarigo, J.J., González-Barcala, F.J. San José, E, et al.

"CD26 and asthma: a comprehensive review." Clin Rev Allergy Immunol 56.2

(2019): 139-60.

85. Wang, L., Gao, P., Zhang, M., et al.

"Prevalence and ethnic pattern of diabetes and prediabetes in China in 2013."

JAMA 317.24 (2017): 2515-23.

86. Drucker D.J.

"Coronavirus Infections and type 2 diabetes." Endocrine Reviews 41.3 (2020):

$1-13$

87. Gupta, R., Ghosh, A., Singh, A.K., Misra, A.

"Clinical considerations for patients with diabetes in times of COVID-19

epidemic". Diabetes Metab Syndr 14.3 (2020): 211-2.

88. Pal, R. Bhadada, S.K.

"Should anti-diabetic medications be reconsidered amid COVID-19

pandemic?" Diabetes Res Clin Pract 10 (2020): 108146.

89. Chen, Y., Yang, D., Cheng, B., et al.

"Clinical characteristics and outcomes of patients with diabetes and COVID-19

in association with glucose-lowering medication." Diabetes Care 43.7 (2020):

1399-407.

90. Gupta, R., Hussain, A., Misra, A.

"Diabetes and COVID-19: evidence, current status and unanswered research questions." Eur J Clin Nutr 74 (2020): 864-70.

91. Tripathy, D., Daniele, G., Fiorentino, T.V., et al.

"Pioglitazone improves glucose metabolism and modulates skeletal muscle

TIMP-3-TACE dyad in type 2 diabetes mellitus: a randomised, double-blind,

placebo-controlled, mechanistic study." Diabetologia 56.10 (2013): 2153-63.

92. Romaní-Pérez, M., Outeiriño-Iglesias, V., Moya, C.M., et al.

"Activation of the GLP-1 receptor by liraglutide increases ACE2 expression, reversing

right ventricle hypertrophy, and improving the production of SP-A and SP-B in the

lungs of type 1 diabetes rats."Endocrinology 156.10 (2015): 3559-69.

93. Kawanami, D., Matoba, K., Takeda, Y., et al.

"SGLT2 inhibitors as a therapeutic option for diabetic nephropathy." Int J Mol Sci 18.5 (2017):1083.

94. Klonoff, D.C. Umpierrez, G.E.

"Letter to the Editor: COVID-19 in patients with diabetes: risk factors that

increase morbidity." Metabolism 108 (2020): 154224

95. lacobellis, $G$.

"COVID-19 and diabetes: Can DPP4 inhibition play a role?" Diabetes Res Clin

Pract 162 (2020): 108125

96. Ceriello, A., Stoian, A.P., Rizzo, M.

"COVID-19 and diabetes management: What should be considered?"

Diabetes Res Clin Pract 163 (2020): 108151.
97. Stoian, A.P., Banerjee, Y., Rizvi, A.A., Rizzo, M.

"Diabetes and the COVID-19 pandemic how insights from recent experience might guide future management." Metab Syndr Relat Disord 18.4 (2020): 173-5. 98. Crouse, A.B., Grimes, T., Li, P., et al.

"Metformin use is associated with reduced mortality in a diverse population with COVID-19 and diabetes." Front Endocrinol 11 (2021): 600439.

99. Grasselli, G., Zangrillo, A., Zanella, A., et al.

"Baseline characteristics and outcomes of 1591 patients infected with SARS-CoV-2 admitted to ICUs of the Lombardy Region, Italy." JAMA 323.16 (2020): 1574-81.

100. Solerte, S.B., D'Addio, F., Trevisan, R., et al.

"Sitagliptin treatment at the time of hospitalization was associated with reduced mortality in patients with type 2 diabetes and COVID-19: multicenter, case-control, retrospective, observational study." Diabetes Care $43.12(2020): 2999-3006$

101. Bornstein, SR Rubino, F Khunti, K et al.

"Practical recommendations for the management of diabetes in patients with COVID-19." Lancet Diabetes Endocrinol 8.6 (2020): 546-50.

102. Diaz-Ramos, A. Eilbert, W. Marquez, D.

"Euglycemic diabetic ketoacidosis associated with sodium-glucose cotransporter-2 inhibitor use: a case report and review of the literature." Int Emerg Med 12.1 (2019): 27.

103. Centers for Disease Control and Prevention

"Coronavirus disease 2019 (COVID-19) and diabetes: the importance of prevention, management, and support."Available from: [www.cdc.gov/coronavirus/2019-

ncov/cdcresponse/about-COVID-19.html], last accessed Feb 22, 2021.

104. Korytkowski, M., Antinori-Lent, K., Drincic, A., et al.

"A pragmatic approach to inpatient diabetes management during the

COVID-19 pandemic." J Clin Endocrinol \& Metab 105.9 (2020): 342

105. Ng, K.E., Rickard, J.P.

"The effect of COVID-19 on patients with diabetes". US Pharm 45.11 (2020):

9-12.

106. Prattichizzo, F., La Sala, L., Rydén, L., et al.

"Glucose-lowering therapies in patients with type 2 diabetes and

cardiovascular diseases" Eur J Prev Cardiol 26 Suppl 2 (2019): 73-80

107. Wilding, J., Fernando, K., Milne, N, et al.

"SGLT2 inhibitors in type 2 diabetes management: key evidence and implications for clinical practice." Diabetes Ther 9.5 (2018): 1757-73. 108. Meyer, E.J., Gabb, G., Jesudason, D.

"SGLT2 inhibitor-associated euglycemic diabetic ketoacidosis: a South Australian clinical case series and Australian spontaneous adverse event notifications." Diabetes Care 41.4 (2018): e47-9.

109. (a), X.

"COVID-19: immunopathology and its implications for therapy." Nat Rev Immunol 20 (2020): 269-70.

110. European Medicines Agency.

"EMA advises continued use of medicines for hypertension, heart or kidney disease during COVID-19 pandemic."Available from: [https://www.ema.europa. eu/en/news/ema-advises-continued-use-medicines-hypertension-heartkidney-disease-during-covid-19-pandemic], last accessed Feb 22, 2021 111. Gomez-Peralta, F., Abreu, C., Gomez-Rodriguez, S., et al.

"Safety and efficacy of DPP4 inhibitor and basal insulin in type 2 diabetes: an updated review and challenging clinical scenarios." Diabetes Ther 9.5 (2018): 1775-89.

112. Rizzo, M., Nikolic, D., Banach, M., et al.

"Incretin-based therapies, glucometabolic health and endovascular inflammation." Curr Pharm Des 20.31(2014): 4953-60.

113. Rizzo, M., Nikolic, D., Patti, A.M., et al.

"GLP-1 receptor agonists and reduction of cardiometabolic risk: Potential underlying mechanisms." Biochim Biophys Acta Mol Basis Dis 1864.9 Pt B

(2018): 2814-21.

114. He, J., Yuan, G., Cheng, F., et al.

"Mast cell and M1 macrophage infiltration and local pro-inflammatory factors were attenuated with incretin-based therapies in obesity-related glomerulopathy." Metab Syndr Relat Disord 15.7 (2017): 344-53.

115. Amin, E.F., Rifaai, R.A., Abdel-Latif, R.G.

"Empagliflozin attenuates transient cerebral ischemia/reperfusion injury in hyperglycemic rats via repressing oxidative-inflammatory-apoptotic pathway." Fundam Clin Pharmacol 34.5 (2020): 548-58.

116. Ceriello, A.

"Thiazolidinediones as anti-inflammatory and anti-atherogenic agents." Diabetes Metab Res Rev 24.1 (2008): 14-26.

117. Deane, A.M., Horowitz, M.

"Comment. Is incretin-based therapy ready for the care of hospitalized patients with type 2 diabetes?" Diabetes Care 37.2 (2014): e40-1.

118. Inzucchi, S.E., Bergenstal, R.M., Buse, J.B., et al.

"Management of hyperglycemia in type 2 diabetes: a patient-centered approach: Position statement of the American Diabetes Association (ADA) and the European Association for the Study of Diabetes (EASD)."Diabetes Care 35.6 (2012): 1364-79

119. Bangash, M.N., Patel, J., Parekh, D.

"COVID-19 and the liver: little cause for concern." Lancet Gastroenterol

(1) $15.6(202$

120. Dardano, A., Del Prato, $S$

Metformin: an inexpensive and effective treatment in people with diabetes and COVID-19?" Lancet Healthy Longev 21 (2021): e6-e7.

121. Smith, G.D. Amos, T.A. Mahler, R., Peters, T.J.

"Effect of chloroquine on insulin and glucose homoeostasis in normal subjects and patients with non-insulin-dependent diabetes mellitus." Br Med I (Clin Res Ed) 294.6570 (1987): 465-7. 
122. Quatraro, A., Consoli, G., Magno, M., et al.

"Hydroxychloroquine in decompensated, treatment-refractory noninsulindependent diabetes mellitus. A new job for an old drug?" Ann Intern Med 112.9 (1990): 678-81.

123. Rekedal, L.R., Massarotti, E, Garg, R, et al.

"Changes in glycosylated hemoglobin after initiation of hydroxychloroquine or methotrexate treatment in diabetes patients with rheumatic diseases." Arthritis Rheum 62.12 (2010): 3569-73.

124. Gerstein, H.C., Thorpe, K.E., Taylor, D.W., Haynes, R.B.

"The effectiveness of hydroxychloroquine in patients with type 2 diabetes mellitus who are refractory to sulfonylureas - a randomized trial." Diabetes Res Clin Pract 55.3 (2002): 209-19.

125. Emami, J., Pasutto, F.M., Mercer, J.R., Jamali, F.

"Inhibition of insulin metabolism by hydroxychloroquine and its enantiomers in cytosolic fraction of liver homogenates from healthy and diabetic rats." Life Sci 64.5 (1999): 325-35.

126. Penlioglou, T., Papachristou, S., Papanas, N.

"COVID-19 and diabetes mellitus: May old anti-diabetic agents become the new philosopher's stone?" Diabetes Ther 11 (2020): 1195-7.

127. Mercuro, N.J., Yen, C.F., Shim, D.J., et al.

"Risk of QT interval prolongation associated with use of hydroxychloroquine with or without concomitant azithromycin among hospitalized patients testing positive for coronavirus disease 2019 (COVID-19)."JAMA Cardiol 5.9 (2020): 1036-41.

128. Bessière, F., Roccia, H., Delinière, A., et al.

"Assessment of QT intervals in a case series of patients with coronavirus disease 2019 (COVID-19) infection treated with hydroxychloroquine alone or in combination with azithromycin in an intensive care unit." JAMA Cardiol 5.9 (2020): 1067-9. 129. Satarker, S., Ahuja, T., Banerjee, M., et al.

"Hydroxychloroquine in COVID-19: potential mechanism of action against

SARS-CoV-2." Curr Pharmacol Rep 6 (2020): 203-11.

130. Wasko, M.C.M., McClure, C.K., Kelsey, S.F, et al.

"Antidiabetogenic effects of hydroxychloroquine on insulin sensitivity and

beta cell function: a randomized trial." Diabetologia 58.10 (2015): 2336-43.

131. Chakravarti, H.N., Nag, A

"Efficacy and safety of hydroxychloroquine as add-on therapy in uncontrolled type 2 diabetes patients who were using two oral antidiabetic drugs."

Endocrinol Invest 44.3 (2021): 481-92.

132. Gupta, A.

"Real-world clinical effectiveness and tolerability of hydroxychloroquine $400 \mathrm{mg}$ in uncontrolled type 2 diabetes subjects who are not willing to initiate insulin therapy (HYQ-Real-World study)."Curr Diabetes Rev 15.6 (2019): 510-9. 133. Shojania, K., Koehler, B.E., Elliott, T.

"Hypoglycemia induced by hydroxychloroquine in a type II diabetic treated for polyarthritis". J Rheumatol 26.1 (1999): 195-6.

134. Stoian, A.P., Catrinoiu, D., Rizzo, M., Ceriello, A.

"Hydroxychloroquine, COVID-19 and diabetes. Why it is a different story."

Diabetes Metab Res Rev (2020). D01: $10.1002 / d m r r 3379$

135. The COVID-19 RISK and Treatments (CORIST) Collaboration.

"Use of hydroxychloroquine in hospitalised COVID-19 patients is associated

with reduced mortality. Findings from the observational multicentre Italian

CORIST study." Eur J Intern Med 82 (2020): 38-47.

136. Hernandez, A.V., Roman, Y., Pasupuleti, V., et al.

"Hydroxychloroquine or chloroquine for treatment or prophylaxis of

COVID-19: a living systematic review."Ann Intern Med 173.4 (2020): 287-96.

137. Lim, S., Bae, J.H., Kwon, H.S., Nauck, M.A.

"COVID-19 and diabetes mellitus: from pathophysiology to clinical

management" "Nat Rev Endocrinol 17.1 (2021):11-30.

138. Carrasco-Sánchez, F.., López-Carmona, M.D., Martínez-Marcos, F.., et al.

"Admission hyperglycaemia as a predictor of mortality in patients

hospitalized with COVID-19 regardless of diabetes status: data from the

Spanish SEMI-COVID-19 Registry."Ann Med 53.1 (2021): 103-16.

139. Mendez, C.E., Umpierrez, G.E.

"Pharmacotherapy for hyperglycemia in noncritically ill hospitalized patients." Diabetes Spectr 27.3 (2014): 180-8.

140. Moghissi, E.S., Korytkowski, M.T., DiNardo, M., et al.

"American Association of Clinical Endocrinologists and American Diabetes

Association consensus statement on inpatient glycemic control." Diabetes Care

32.6 (2009): 1119-31.

141. Riddle, M.C., Buse, J.B., Franks, P.W., et al.

"COVID-19 in people with diabetes: urgently needed lessons from early

reports." Diabetes Care 43.7 (2020): 1378-81.

142. Novack, V., Eisinger, M., Frenkel, A., et al.

"The effects of statin therapy on inflammatory cytokines in patients with

bacterial infections a randomized double-blind placebo controlled clinical

trial." Intensive Care Med 35.7 (2009): 1255-60.

143. Papazian, L., Roch, A., Charles, P.E., et al.

"Effect of statin therapy on mortality in patients with ventilator-associated

pneumonia: a randomized clinical trial."JAMA 310.16 (2013): 1692-700.

144. Zhang, X.J., Qin, J.J., Cheng, X., et al.

"In-hospital use of statins is associated with a reduced risk of mortality among individuals with COVID-19" (ell Metab 322 (2020): 176-87.

145. Chen, N., Zhou, M., Dong, X., et al

"Epidemiological and clinical characteristics of 99 cases of 2019 novel coronavirus pneumonia in Wuhan, China: a descriptive study."Lancet 395 (2020): 507-13.

146. Klok, F.A., Kruip, M.J.H.A., van der Meer, N.J.M., et al.

"Confirmation of the high cumulative incidence of thrombotic complications in critically ill ICU patients with COVID-19: an updated analysis."Thromb Res $191(2020): 148-50$
147. Connors, J.M., Levy, J.H.

"COVID-19 and its implications for thrombosis and anticoagulation." Blood 135.23 (2020): 2033-40.

148. Tang, N., Li, D., Wang, X., Sun, Z.

"Abnormal coagulation parameters are associated with poor prognosis in patients with novel coronavirus pneumonia."J Thromb Haemost 18.4 (2020): 844-7.

149. Moores, L.K., Tritschler, T., Brosnahan, S., et al.

"Prevention, diagnosis, and treatment of VTE in patients with coronavirus disease 2019: (HEST guideline and expert panel report." Chest 158.3 (2020) $1143-63$.

150 . Oxford, A.E. Halla, F, Robertson, E. B. Morrison, B.E.

"Endothelial cell contributions to COVID-19". Pathogens 9.10 (2020): 785.

151. Ferrario, C.M., Jessup, J., Chappell, M.C., et al.

"Effect of angiotensin-converting enzyme inhibition and angiotensin receptor blockers on cardiac angiotensin-converting enzyme 2." Circulation 111.20 (2005): 2605-10.

152. Varga, Z., Flammer A.J., Steiger, P., et al.

"Endothelial cell infection and endotheliitis in COVID-19." Lancet 395.10234 (2020): 1417-8

153. Fei, Y., Tang, N., Liu, H., Cao, W.

"Coagulation dysfunction: a hallmark in COVID-19."Arch Pathol Lab Med

144.10 (2020): 1223-9.

154. Chung, W.S., Lin, C.L., Kao, C.H.

"Diabetes increases the risk of deep-vein thrombosis and pulmonary embolism.

A population-based cohort study."Thromb Haemost 114.4 (2015): 812-8.

155. Zhao, Z., Wang, S., Ma, W., et al.

"Diabetes mellitus increases the incidence of deep vein thrombosis after total

knee arthroplasty." Arch Orthop Trauma Surg 134.1 (2014): 79-83.

156. Galana, P. Bertoletti, L. Amitrano, M. et al.

"Predictors of post-thrombotic ulcer after acute DVT: the RIETE registry."

Thromb Haemost 118.2 (2018): 320-8.

157. Olesen, K.K.W., Madsen, M., Gyldenkerne, C., et al.

"Diabetes mellitus is associated with increased risk of ischemic stroke in

patients with and without coronary artery disease." Stroke 50.12 (2019):

3347-54.

158. Overvad, T.F., Skiøth, F. Lip, G.Y., et al.

"Duration of diabetes mellitus and risk of thromboembolism and bleeding in atrial fibrillation: nationwide cohort study." Stroke 46.8 (2015): 2168-74.

159. Arepally, G.M. Ortel, T.L.

"Changing practice of anticoagulation: will target-specific anticoagulants

replace warfarin?" Annu Rev Med 66 (2015): 241-53.

160. Tang, N., Bai, H., Chen, X., et a

"Anticoagulant treatment is associated with decreased mortality in severe coronavirus disease 2019 patients with coagulopathy." JThromb Haemost 18.5 (2020): 1094-9.

161. Lim, S., Lee, G.Y., Park, H.S., et al.

"Attenuation of carotid neointimal formation after direct delivery of a recombinant adenovirus expressing glucagon-like peptide-1 in diabetic rats." Cardiovasc Res 113.2 (2017): 183-94

162. Vinué, Á., Navarro, J., Herrero-Cervera, A., et al.

"The GLP-1 analogue lixisenatide decreases atherosclerosis in insulinresistant mice by modulating macrophage phenotype." Diabetologia 60.9 (2017): 1801-12

63. Gerstein H.C. Colhoun, H.M. Dagenais, G.R. et al.

"Dulaglutide and cardiovascular outcomes in type 2 diabetes (REWIND):

a double-blind, randomised placebo-controlled trial." Lancet 394.10193

(2019): 121-30.

164. Li, H., Zhou, Y, Zhang M. et al.

"Updated approaches against SARS-CoV-2." Antimicrob Agents Chemother 64.6 (2020): e00483-20.

165. World Health Organization.

"Overview of the types/classes of candidate therapeutics 2020." (2020).

166. Kupferschmidt, K., Cohen, J.

"Race to find COVID-19 treatments accelerates". Science 367 6485 (2020): 1412-3. 167. Hoffmann, M., Kleine-Weber, H., Schroeder, S., et al.

"SARS-COV-2 cell entry depends on ACE2 and TMPRSS2 and is blocked by a clinically proven protease inhibitor." Cell 181.2 (2020): 271-80.

168. Ito, T., Otsuki, M. Itoi, T., et al.

"Pancreatic diabetes in a follow-up survey of chronic pancreatitis in Japan." Gastroenterol 42.4 (2007): 291-7.

169. Jia, D., Taguchi, M., Otsuki, M.

"Synthetic protease inhibitor camostat prevents and reverses dyslipidemia, insulin secretory defects, and histological abnormalities of the pancreas in genetically obese and diabetic rats." Metabolism 54.5 (2005): 619-27. 170. Albarazanii, K., Jennis, M., Cavanaugh, C.R., et al.

"Intestinal serine protease inhibition increases FGF21 and improves metabolism in obese mice." Am J Physiol Gastrointest Liver Physiol 316.5 (2019): G653-67. 171. Katulanda, P., Dissanayake, H.A., Ranathunga I., et al.

"Prevention and management of COVID-19 among patients with diabetes: an appraisal of the literature." Diabetologia 63.8 (2020): 1440-52.

172. Bonaventura, A., Montecucco, F.

"Steroid-induced hyperglycemia: an underdiagnosed problem or clinica inertia? A narrative review." Diabetes Res Clin Pract 139 (2018): 203-20 173. The RECOVERY Collaborative Group.

"Dexamethasone in hospitalized patients with Covid-19 - preliminary report." N Engl J Med (2020). DOl: 10.1056/NEJMoa2021436
174. Tomazini, B.M., Maia, I.S., Cavalcanti, A.B., et al.

Effect of dexamethasone on days a live and ventilator-free in patients with moderate or severe acute respiratory distress syndrome and COVID-19: the CoDEX randomized clinical trial." JAMA 324.13 (2020): 1307-16.

175. The WHO Rapid Evidence Appraisal for COVID-19 Therapies (REACT) Working Group

"Association between administration of systemic corticosteroids and mortality among critically ill patients with COVID-19: a meta-analysis." JAMA $324.13(2020): 1330-41$

176. Angus, D.C., Derde, L., Al-Beidh, F., et al.

"Effect of hydrocortisone on mortality and organ support in patients with severe COVID-19: The REMAP-CAP COVID-19 Corticosteroid Domain Randomized Clinical Trial." JAMA 324.13 (2020): 1317-29.

177. Dequin, P.F., Heming, N. Meziani, F., et al.

"Effect of hydrocortisone on 21-day mortality or respiratory support among critically ill patients with COVID-19: a randomized clinical trial." JAMA 324.13 (2020): 1298-306.

178 . Russell, CD, Millar, JE, Baillie, JK K.

"Clinical evidence does not support corticosteroid treatment for 2019-nCoV

lung injury." Lancet 395.10223 (2020): 473-5.

179. Clore, J.N. Thurby-Hay, L.

"Glucocorticoid-induced hyperglycemia." Endocr Pract 15.5 (2009): 469-74 180. Anesi, G.L., Manaker, S., Finlay, G.

"Coronavirus disease 2019 (COVID-19): Critical care issues. UpToDate."

Available from: [https://www.uptodate.com/contents/coronavirus-disease2019-covid-19-critical-care-issues], last accessed Feb 22, 2021.

181. Caly, L., Druce, J.D., Catton, M.G., et al.

"The FDA approved Drug lvermectin inhibits the replication of SARS-CoV-2 in vitro, Antiviral Research." DOl: 10.1016/j.antiviral.2020.104787

182. Li, Y.N., Su, Y.

"Remdesivir attenuates high fat diet (HFD)-induced NAFLD by regulating epatocyte dyslipidemia and inflammation via the suppression of STING." Biochem Biophys Res Commun 526.2 (2020): 381-8.

183. Beigel, J. . Tomashek K M. Dodd L E, et a

"Remdesivir for the treatment of Covid-19 - preliminary report."N Engl J Med 383 (2020): 1813-26.

184. Wang, Y., Zhang, D., Du, G., et al.

"Remdesivir in adults with severe COVID-19: a randomised, double-blind, placebocontrolled, multicentre trial." Lancet 395.10236 (2020): 1569-78. 185. Food and Drug Administration.

"Remdesivir: EUA letter of authorisation." (2020). Available from: [https:// www.fda.gov/media/137564/download], last accessed Feb 22, 2021

186. Chu, C.M., Cheng, V.C.C., Hung, I.F.N., et al.

Role of lopinavir/ritonavir in the treatment of SARS: initial virological and clinical findings."Thorax 9.3 (2004): 252-6.

187. Hull, M.W., Montaner, J.S.G.

"Ritonavir-boosted protease inhibitors in HIV therapy."Ann Med 43.5 (2011): $375-88$

188. Woerle, H.J., Szoke, E., Meyer, C., et al.

Mechanisms for the deterioration in glucose tolerance associated with HIV protease inhibitor regimens." Diabetes Am J Physiol Endocrinol Metab 290.1 (2006): E67-E77.

189. Tsiodras, S., Mantzoros, C., Hammer, S., Samore, M.

"Effects of protease inhibitors on hyperglycemia, hyperlipidemia, and lipodystrophy: a 5-year cohort study." Arch Intern Med 160.13 (2000): 2050-6.

90. Brown, T. Cole, SR, Li, X et a

"Antiretroviral therapy and the prevalence and incidence of diabetes mellitus in the multicenter AIDS cohort study." Arch Intern Med 165.10 (2005):

1179-84

191. Kan, V.L., Nylen, ES.

"Diabetic ketoacidosis in an HIV patient: a new mechanism of HIV protease nhibitor-induced glucose intolerance." AIDS 13.14 (1999): 1987-9.

192 Cao, B., Wang, Y. Wen, D., et al.

"A trial of lopinavir-ritonavir in adults hospitalized with severe Covid-19." N Engl J Med 382 (2020): 1787-99.

193. Zhou, Y. Vedantham, P. Lu, K, et al.

"Protease inhibitors targeting coronavirus and filovirus entry." Antiviral Res 116 (2015): 76-84.

194. Pardi, N., Hogan, M.J., Porter, F.W. Weissman, D.

"mRNA vaccines - a new era in vaccinology." Nat Rev Drug Discov 17.4 (2018): 261-79.

195. Hodgson, J.

"The pandemic nipeline" Nat Biotechnol 38.5 (2020): 523-32

196. Parnham, M.J., Haber, V.E., Giamarellos-Bourboulis, E.J., et al. "Azithromycin: Mechanisms of action and their relevance for clinica applications" Pharmacol Ther 143.2 (2014): 225-45.

197. Gautret, P., Lagier, J.-C., Parola, P., et al.

"Hydroxychloroquine and azithromycin as a treatment of COVID-19: results of an open-label non-randomized clinical trial." Int J Antimicrob Agents 56.1 (2020): 105949

198. Duan, K., Liu, B., Li, C., et al.

"Effectiveness of convalescent plasma therapy in severe COVID-19 patients". Proc Natl Acad Sci U S A 117.17 (2020): 9490-6.

199. Rubino, F., Amiel, S.A., Zimmet, P., et al.

"New-onset diabetes in Covid-19." New Engl J Med 383.8 (2020): 789-90.

DOI: 10.1056/NEJMc2018688 


\section{DIABETES MELLITUS IN COMBINATION WITH COVID-19: MODERN VIEWS ON THERAPY Literature review}

V.I. Tsymbaliuk, MD, professor, president of the NAMS of Ukraine, academician of the NAMS of Ukraine, corresponding member of the NAS of Ukraine, Kyiv M.D. Tronko, MD, professor, vice-president of the NAMS of Ukraine, academician of the NAMS of Ukraine, corresponding member of the NAS of Ukraine, director of the SI "V.P. Komisarenko Institute of Endocrinology and Metabolism of the NAMS of Ukraine", Kyiv

Y.G. Antypkin, MD, professor, academician of the NAMS of Ukraine, academician-secretary of the Clinical Medicine Department of the NAMS of Ukraine, director of the SI "O.M. Lukyanova Institute of Pediatrics, Obstetrics and Gynecology of the NAMS of Ukraine", Kyiv

S.V. Kushnirenko, MD, associate professor, Department of nephrology and renal replacement therapy, dean of Therapeutic Faculty, Shupyk National Healthcare University of Ukraine, Kyiv V.V. Popova, MD, head of the Department of Preventive Diabetology, SI "V.P. Komisarenko Institute of Endocrinology and Metabolism of the NAMS of Ukraine”, Kyiv

Diabetic patients are in the spotlight from the early stages of a pandemic, as growing epidemiological data show they are at higher risk for severe clinical outcomes from COVID-19. As the global COVID-19 pandemic continues to evolve, it is also becoming increasingly apparent that the interactions between COVID-19 and diabetes mellitus (DM) are complex pathophysiological mechanisms. The outcome of COVID-19 is more severe in people with DM, which has the potential to accelerate the onset of acute metabolic complications of DM such as diabetic ketoacidosis and hyperglycemia. These mechanisms underlying these associations remain unclear, but they likely include the angiotensin converting enzyme receptor 2, a binding site for SARS-CoV-2, which is expressed in key metabolic organs such as in the pancreas, in particular in $\beta$-cells. The potential $\beta$-cell tropism of SARS-CoV-2 can damage cells and impair insulin secretion, causing hyperglycemia and ketoacidosis. Understanding the bidirectional interaction between DM and COVID-19 will be critical to protecting and treating people with DM. Current epidemiological data on COVID-19 do not support the hypothesis that diabetic patients are at increased risk of infection compared to the general population. To date, it has been established that decompensated DM is an independent factor that aggravates the course of coronavirus infection and significantly increases the risk of a fatal outcome of the disease.

The review provides a brief summary of the evolution of pathogenetic and clinical aspects for understanding the mechanisms of this pathological tandem, as well as therapeutic strategies for treating patients with COVID-19 and DM. As the incidence of DM continues to rise globally, more than ever, diabetes prevention and control must be a priority for health systems around the world.

Keywords: COVID-19, angiotensin-converting enzyme 2, diabetes mellitus.

\section{ЦУКРОВИЙ ДІАБЕТ У ПОЕДНАННЫ З СОVID-19: СУЧАСНІ ПОГЛЯДИ НА ЛІКУВАННЯ Огляд літератури}

В.І. Цимбалюк, Д. мед. н., професор, президент НАМН України, академік НАМН України, член-кореспондент НАН України, м. Київ

М.Д. Тронько, Д. мед. Н., професор, віце-президент НАМН України, академік НАМН України, член-кореспондент НАН України, директор ДУ «|нститут ендокринології та обміну речовин ім. В.П. Комісаренка НАМН України», м. Київ

Ю.Г. Антипкін, д. мед. Н., професор, академік НАМН України, академік-секретар відділення клінічної медицини НАМН України, директор ДУ «|нститут педіатрії, акушерства і гінекології ім. акад. О.М. Лук'янової НАМН України», м. Київ

С.В. Кушніренко, Д. мед. Н., доцент кафедри нефрології та нирково-замісної терапії, декан терапевтичного факультету Національного університету охорони здоров'я України ім. П.Л. Шупика, м. Київ

В.В. Попова, д. мед. н., завідувачка відділом профілактичної діабетології ДУ «ннститут ендокринології та обміну речовин ім. В.П. Комісаренка НАМН України», м. Київ Пацієнти з цукровим діабетом (ЦД) перебувають у центрі уваги з ранніх стадій пандемії, оскільки, за даними епідеміологічних досліджень, вони схильні до вищого ризику важких наслідків COVID-19. В той час як глобальна пандемія COVID-19 продовжує еволюціонувати, також стає очевидним, що взаємодія між COVID-19 і ЦLД має СКладні патофізіологічні механізми. Наслідки COVID-19 важчі у людей із ЦД, який здатний прискорити виникнення гострих метаболічних ускладнень, таких як діабетичний кетоацидоз і гіперглікемія. Механізми, що лежать в основі цих зв'язків, залишаються нез'ясованими, але вони, ймовірно, включають рецептори ангіотензинперетворюючого ферменту 2, сайт зв'язування для SARS-CoV-2, який експресується в ключових метаболічних органах, таких як підшлункова залоза, зокрема, З-клітини. Потенційно тропізм SARS-CoV-2 до ß-клітин може призвести до пошкодження клітин і порушення секреції інсуліну, викликаючи гіперглікемію і кетоацидоз. 3'ясування двонаправленої взаємодії між ЦД і COVID-19 матиме вирішальне значення для захисту та лікування людей із цим захворюванням. Наявні на даний момент епідеміологічні дані про COVID-19 не підтверджують гіпотези про те, що пацієнти з ЦД схильні до підвищеного ризику інфікування порівняно із загальною популяцією. На сьогоднішній день встановлено, що декомпенсований ЦД є незалежним чинником, що має обтяжуючий характер протягом коронавірусної інфекції та достовірно підвищує ризики фатального наслідку захворювання.

В огляді представлено коротке резюме еволюції патогенетичних і клінічних аспектів розуміння механізмів цього патологічного тандему, а також терапевтичних стратегій щодо лікування пацієнтів із COVID-19 і ЦД. Оскільки рівень захворюваності на ЦД продовжує зростати в усьому світі, нині, більш ніж коли-небудь, профілактика ЦД і боротьба з ним повинна стати пріоритеТом систем охорони здоров'я всіх країн світу.

Ключові слова: COVID-19, ангіотензинперетворюючий фермент 2, цукровий діабет.

\section{САХАРНЫЙ ДИАБЕТ В СОЧЕТАНИИ С COVID-19: СОВРЕМЕННЫЕ ВЗГЛЯДЫ НА ЛЕЧЕНИЕ Обзор литературы}

В.И. Цымбалюк, д. мед. н., профессор, президент НАМН Украины, академик НАМН Украины, член-корреспондент НАН Украины, г. Киев

Н.Д. Тронько, д. мед. Н., профессор, вице-президент НАМНУкраины, академик НАМНУкраины, член-кореспондент НАН Украины, директор ГУ «Институт эндокринологии и обмена веществ им. В.П. Комиссаренко НАМН Украиным, г. Киев

Ю.Г. Антипкин, Д. мед. Н., профессор, академик НАМН Украины, академик-секретарь отделения клинической медицины НАМН Украины, директор ГУ «Институт педиатрии, акушерства и гинекологии им. акад. Е.М. Лукьяновой НАМН Украины», г. Киев

С.В. Кушниренко, Д. мед. Н., доцент кафедры нефрологии и почечно-заместительной терапии, декан терапевтического факультета Национального университета здравоохранения Украины им П.Л. Шупика, г. Киев

В.В. Попова, Д. мед. Н., заведующая отделом профилактической диабетологии ГУ «Институт эндокринологии и обмена веществ им. В.П. Комиссаренко НАМН Украины», г. Киев

Пациенты с сахарным диабетом (СД) находятся в центре внимания с ранних стадий пандемии, поскольку растущие эпидемиологические данные показывают, что они подвержены более высокому риску тяжелых клинических исходов COVID-19. По мере того как глобальная пандемия COVID-19 продолжает развиваться, также становится все более очевидным, что взаимодействие между COVID-19 и СД представляет собой сложные патофизиологические механизмы. Исходы COVID-19 более тяжелые у людей с CД, который способен ускорить возникновение острых метаболических осложнений СД, таких как диабетический кетоацидоз и гипергликемия. Эти механизмы, лежащие в основе данных связей, остаются неясными, но они, вероятно, включают рецепторы ангиотензинпревращающего фермента 2, сайт связывания для SARS-CoV-2, который экспрессируется В ключевых метаболических органах, таких как поджелудочная железа, в частности, в В-клетках. Потенциально тропизм SARS-CoV-2 к ß-клеткам может привести к повреждению клеток и нарушению секреции инсулина, вызывая гипергликемию и кетоацидоз. Понимание двунаправленного взаимодействия между СД и COVID-19 будет иметь решающее значение для защиты и лечения людей с СД. Имеющиеся на данный момент эпидемиологические сведения о COVID-19 не подтверждают гипотезу о том, что пациенты с С Д подвержены повышенному риску инфицирования по сравнению с общей популяцией. На сегодняшний день установлено, что декомпенсированный СД является независимым фактором, отягощающим течение коронавирусной инфекции и достоверно повышающим риски фатального исхода заболевания.

В обзоре представлено краткое резюме эволюции патогенетических и клинических аспектов понимания механизмов данного патологического тандема, а также терапевтических стратегий лечения пациентов с COVID-19 и СД. Поскольку уровень заболеваемости СД продолжает расти во всем мире, сейчас, более чем когда-либо, профилактика СД и борьба с ним должны стать приоритетом систем здравоохранения всех стран мира.

Ключевые слова: COVID-19, ангиотензинпревращающий фермент 2, сахарный диабет. 